\title{
Therapeutic Strategies for Overcoming Immunotherapy Resistance Mediated by Immunosuppressive Factors of the Glioblastoma Microenvironment
}

\author{
Tsubasa Miyazaki ${ }^{1,2, \dagger}$, Eiichi Ishikawa ${ }^{1, *, \dagger}$, Narushi Sugii $^{1}$ and Masahide Matsuda ${ }^{1}$ \\ 1 Department of Neurosurgery, Faculty of Medicine, University of Tsukuba, 1-1-1 Tennodai, Tsukuba, \\ Ibaraki 305-8575, Japan; t-miyazaki@cell-medicine.com (T.M.); narushi-sugii@md.tsukuba.ac.jp (N.S.); \\ m-matsuda@md.tsukuba.ac.jp (M.M.) \\ 2 Cell-Medicine, Inc., Sengen 2-1-6, Tsukuba Science City, Ibaraki 305-0047, Japan \\ * Correspondence: e-ishikawa@md.tsukuba.ac.jp \\ + These authors contributed equally to this work as first authors.
}

Received: 18 June 2020; Accepted: 15 July 2020; Published: 19 July 2020

check for updates

\begin{abstract}
Various mechanisms of treatment resistance have been reported for glioblastoma (GBM) and other tumors. Resistance to immunotherapy in GBM patients may be caused by acquisition of immunosuppressive ability by tumor cells and an altered tumor microenvironment. Although novel strategies using an immune-checkpoint inhibitor (ICI), such as anti-programmed cell death-1 antibody, have been clinically proven to be effective in many types of malignant tumors, such strategies may be insufficient to prevent regrowth in recurrent GBM. The main cause of GBM recurrence may be the existence of an immunosuppressive tumor microenvironment involving immunosuppressive cytokines, extracellular vesicles, chemokines produced by glioma and glioma-initiating cells, immunosuppressive cells, etc. Among these, recent research has paid attention to various immunosuppressive cells-including M2-type macrophages and myeloid-derived suppressor cells - that cause immunosuppression in GBM microenvironments. Here, we review the epidemiological features, tumor immune microenvironment, and associations between the expression of immune checkpoint molecules and the prognosis of GBM. We also reviewed various ongoing or future immunotherapies for GBM. Various strategies, such as a combination of ICI therapies, might overcome these immunosuppressive mechanisms in the GBM microenvironment.
\end{abstract}

Keywords: glioma; immune-checkpoint molecules; immunosuppressive tumor microenvironment; M2-type macrophages; tumor vaccine

\section{Introduction-Glioblastoma and Its Epidemiological Features}

Glioblastoma (GBM) is the most common and lethal malignant brain tumor, classified as grade IV by the World Health Organization (WHO), and reportedly diagnosed in $12.0 \%$ of all brain tumor patients [1-3]. GBM occurs frequently in people aged 50 to 60 years and is more common in men. Even with the current standard adjuvant therapy using temozolomide (TMZ) and radiation therapy (RT), the median relapse-free survival and median overall survival (OS) of GBM patients are 6.9 months and 14.6 months, respectively, and the 5-year survival rate is less than 10\% [4]. Furthermore, in case of recurrence after standard therapy, the median survival time after recurrence is only 1 to 10.8 months, even if conditions such as the Karnofski performance status (KPS), tumor site, tumor volume, and expression of tumor markers are taken into account [5-7]. New treatment strategies for GBM patients are being successively developed. For instance, clinical trial of new drugs such 
as carmustine-loaded polymers (Gliadel wafers) without TMZ [8] and an anti-vascular endothelial growth factor (VEGF) antibody (bevacizumab) added to standard therapies [9] did not significantly improve the OS of initially diagnosed GBM patients.

Many researchers are focusing on various types of tumor proliferation markers, gene mutations/ methylations, and histone mutations of GBM, such as Ki-67; TP53 mutations; epidermal growth factor receptor (EGFR) amplification and its mutant EGFRvIII, isocitrate dehydrogenase (IDH) 1/2 mutation; telomerase reverse transcriptase (TERT) promoter mutation; histone $\mathrm{H} 3$ mutations; epigenetic modifications of O6-methylguanine-DNA methyltransferase (MGMT) promotor methylation; and $1 \mathrm{p} 19 \mathrm{q}$ co-deletion as prognostic markers of malignant glioma $[10,11]$.

In GBM, IDH1/2 mutations and MGMT methylation are already considered prognostic and therapeutic markers but further therapeutic efficacy indicators are desired [10-12]. Anaplastic astrocytomas (WHO grade III) typically have IDH1 mutations and MGMT promotor methylation is an important prognostic marker [13]. Anaplastic oligodendrogliomas (WHO grade III), in contrast, typically have $1 \mathrm{p} 19 \mathrm{q}$ co-deletion in addition to IDH1 mutation and have a better prognosis than GBM, even when they pathologically show necrotic features [14]. Regarding the changes in molecular expression before and after recurrence of GBM, the expression of p53 and EGFRvIII are decreased in recurrent tumor cells $[15,16]$.

\section{Glioblastoma Immune Microenvironment}

Immune status biomarkers, such as the pro-/anti-inflammatory phenotype, infiltration rate, and activation status of tumor-infiltrated lymphocytes (TILs) in the tumor microenvironment and expression of immunosuppressive factors by tumor cells, are considered to be prognostic for various cancers (e.g., breast, colorectal) $[17,18]$.

Immunosuppression is caused by various mechanisms in the tumor microenvironment. Representative immunosuppressive mechanisms include: expression of inhibitory immune checkpoint molecules (ICMs); infiltration of immunosuppressive immune cells, including M2-type macrophages $(\mathrm{M} 2 \mathrm{M} \varphi \mathrm{s})$, forkhead box protein $\mathrm{P} 3$ (FOXP3)-positive regulatory $\mathrm{T}$ cells (Tregs), myeloid-derived suppressor cells (MDSC), and regulatory B cells (Bregs); secretion of immunosuppressive cytokines; and reduced expression of MHC molecules [19]. In the glioma microenvironment, FASL (CD95L) [20], programmed cell death ligand 1/2 (PD-L1/2) [21-25], galectin-1 [26], galectin-9 [27], HVEM [28], B7-H4 (B7x) [29], and CD70/gangliosides [30] expressed on glioma cells act as inhibitory ICMs. Furthermore, AHR and CD39 expressed on TAMs [31], podoplanin (PDPN) expressed on MDSCs [32], and glycoprotein A repetitions predominantly (GARP) expressed on Tregs [33] also cause immunosuppression. As for humoral factors, VEGF [34], macrophage migration inhibitory factor (MIF) [35], IL-6 [29], IL-4/13 [36,37], IL-10, TGF $\beta$ [38], POSTN [39], colony-stimulating factor-1 (CSF-1) [40], CCL2 [41], CXCL12 [42], and COX-2/PGE2 [43] directly or indirectly regulate the immunosuppressive tumor microenvironment. Stat3, an intracellular transducer of immune-related signaling, acts to promote proliferation, angiogenesis, metastasis, and immune escape in tumor cells [44]. In addition, extracellular vesicles containing PD-L1 [45] and miRNA [46] secreted by glioma cells control the immunosuppressive ability of infiltrating immune cells. Alterations to the local nutritional status [47] by indoleamine 2,3 dioxygenase 1 (IDO) expression [48] or Tregs [49], CD39/CD73/A2AR [50], protein arginine methyltransferase 5 (PRMT5) [51], and HIF1 $\alpha$ expression associated with hypoxia during tumor progression [52] also contribute to an immunosuppressive microenvironment surrounding tumor cells. IDO metabolizes tryptophan to kynurenine and induces/activates Tregs in the tumor microenvironment [48]. Furthermore, paracrine crosstalk between tumor cells and immunosuppressive cells, as well as between immunosuppressive cells themselves, augments immunosuppression in the tumor microenvironment $[29,35-43,45,48-50,53]$. Thus, GBM cells and their microenvironment facilitate immunosuppression through a variety of strategies and development of treatments with diversified/comprehensive immunological perspectives is desirable (Figures 1 and 2). 


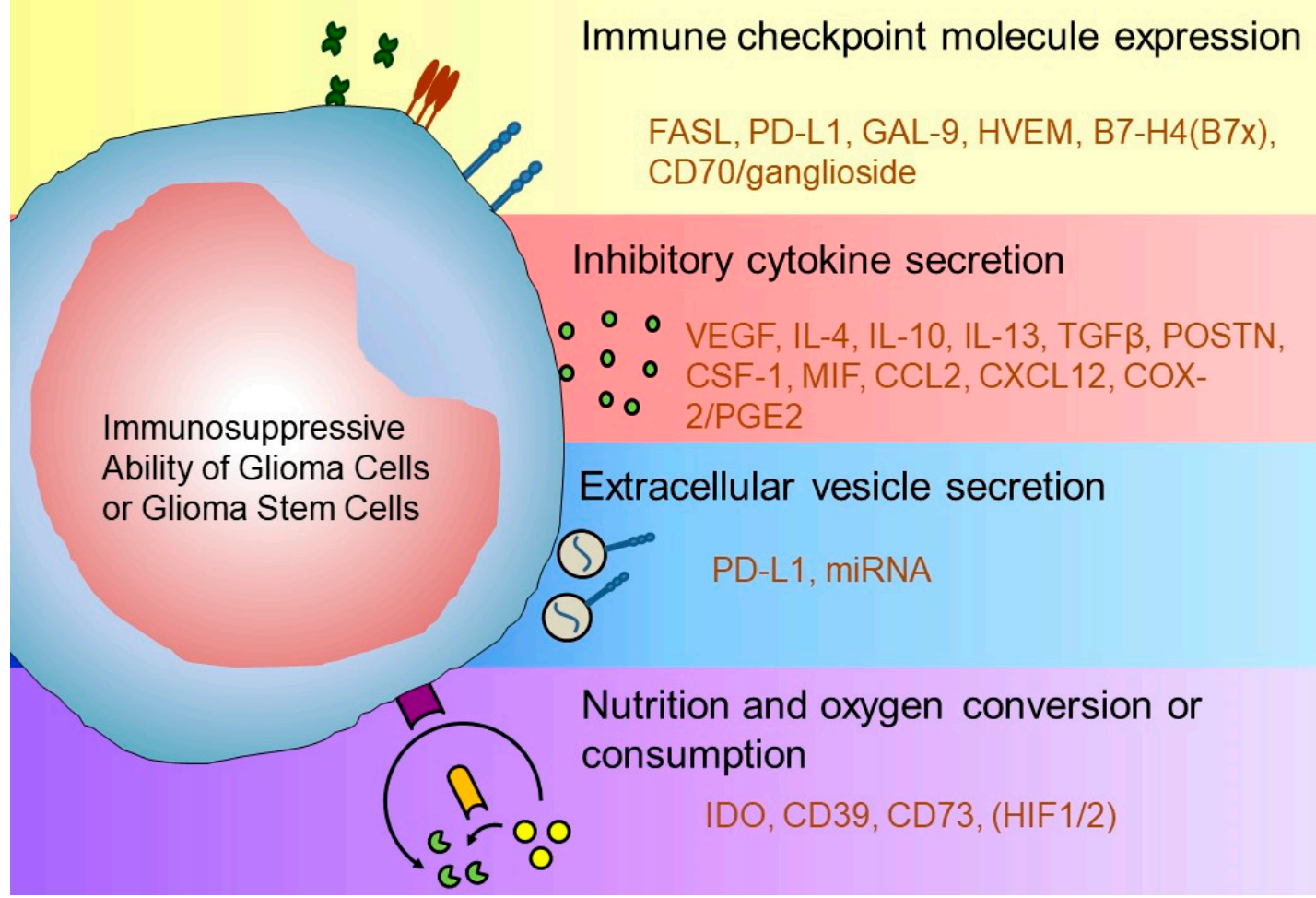

Figure 1. Glioblastoma cell immunosuppressive ability and cell-to-cell interactions in the glioma microenvironment. The immunosuppressive tumor microenvironment is created by altering the immune checkpoint molecule expression, immunosuppressive cytokine secretion, extracellular vesicle secretion, and oxygen nutrition status.

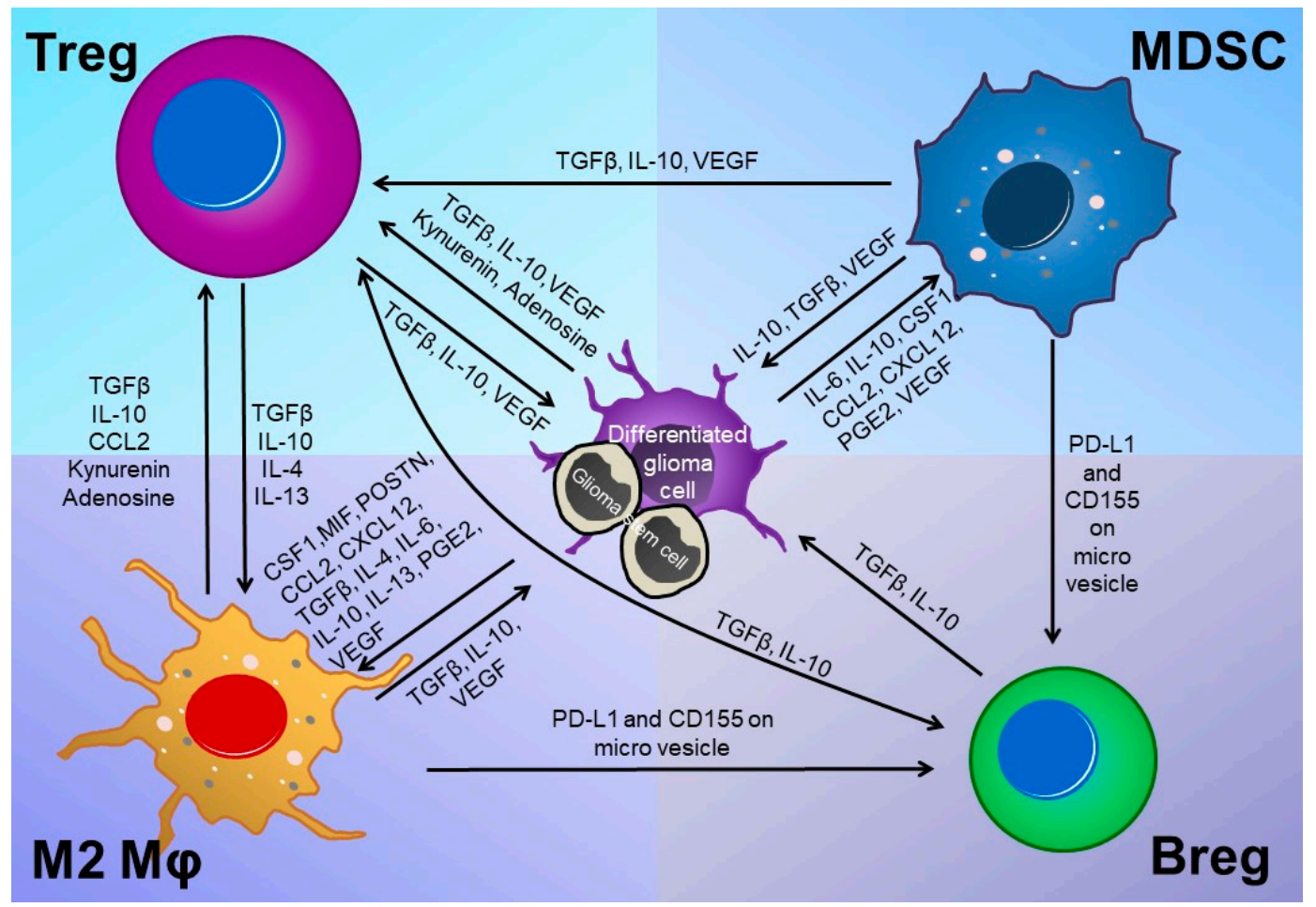

Figure 2. Complex crosstalk among tumor cells and various immune cells in glioma microenvironment. In the glioma microenvironment, the immunosuppressive environment is reinforced by a complex crosstalk between tumor cells and immunosuppressive cells and between different immunosuppressive cells. 


\section{Association between Expression of ICMs and Prognosis in GBM}

The immune system is a biological defense mechanism that has evolved to prevent/eliminate the invasion of external enemies (such as bacteria and viruses) but it also eliminates tumor cells. The effector function of immune cells is controlled by ICM expression. When CD8 T cells attack target cells, the first signal of the MHC molecule carrying the target antigen followed by co-stimulative ICMs-such as CD28, ICOS, or CD134 (OX40)-is required [54]. The expression of NR4A1, which inhibits $\mathrm{T}$ cell effector function, is also an obstacle to immune activation [55] MHC-deficient cells are targeted and attacked by NK cells. In the absence of these co-stimulative ICMs, however, T cells lapse into an anergic, immune-deficient state. Activated CD8 T cells attack target cells one after another while controlling their own activity by the expression of co-inhibitory ICMs such as cytotoxic T-lymphocyte antigen-4 (CTLA-4), PD-1, and T-cell immunoglobulin and mucin domain 3 (TIM-3) to prevent excessive activation and autoimmune effector activity [54]. On the other hand, tumor cells also utilize these inhibitory ICMs for immune escape. Therefore, novel therapies focused on these inhibitory ICMs and T-cell exhaustion have recently been developed [56]. Among them, inhibitory antibodies of the PD-1/PD-L1 pathway have shown therapeutic effects in various types of cancers, especially in high somatic mutation burden tumors such as melanoma and non-small cell lung cancer $[57,58]$. The relationship between PD-1/PD-L1 expression and prognosis has been reported for several types of cancers [59].

The prognostic effect of PD-1/PD-L1 expression in the tumor microenvironment of GBM has also been analyzed. Using immunohistochemical analysis, Nduom and coauthors reported that PD-L1 expression was a poor prognosis marker in 94 GBM patients [25]. Similarly, in the analysis of 17 GBM patient samples, Liu and coauthors found that over 10 PD-L1-expressing cell phenotypes in tumor tissue were associated with poor prognosis [23]. However, in the analysis of PD-L1 mRNA expression in 135 specimens (117 initial specimens and 18 local recurrence specimens), no such correlations were found [21]. We have also previously reported that PD-1/PD-L1 expression in primary tumors does not correlate with GBM prognosis [24]. As described above, the correlation between PD-1/PD-L1 expression and patient prognosis is still controversial in GBM $[21,23,25]$. In addition, infiltration of Tregs and IDO1 expression were reported as poor prognostic factors $[60,61]$. Thus, such molecules in the tumor microenvironment are potential therapeutic targets [62].

\section{GBM Immunotherapy and Microenvironmental Changes after Recurrence}

Immunotherapy for malignant tumors originated in the 1890s, when Dr William Coley discovered the relationship between erysipelas infection and tumor disappearance [63]. Cytokine therapy that administers interleukins and interferons, adoptive immunotherapy that extracts and activates lymphocytes and dendritic cells from the blood, and artificially synthesized cancer vaccine therapy that administers cancer antigens or cancer tissue-processed products added with immune adjuvants have been developed [64]. Our group has previously reported a clinical trial using autologous tumor-specific T lymphocytes [65] and autologous natural killer cells [66] for recurrent malignant glioma. Another report on GBM antitumor therapy compared autologous formalin-fixed tumor vaccine (AFTV), manufactured from autologous formalin-fixed tumor tissue [64], a vaccine with RT [67] and TMZ concomitant with RT standard therapy [68]. In the most recent phase IIa clinical trial, the median OS was 22.2 months and the 3-year survival rate was 38\% [68,69]. The number of TILs was increased in recurrent tumor tissues after AFTV therapy compared with initial tumor tissue and the number of Ki-67-positive tumor cells tended to be decreased [70]. Furthermore, the number of PD-1-positive inactivated/exhausted lymphocytes was increased in recurrent GBM tissue, especially in patients treated with AFTV before recurrence (Figure 3) [24].

Clinical trials on the anti-PD-1 antibody ICI nivolumab failed to show an advantage over control bevacizumab adjuvant therapy for recurrent GBM patients, indicating that the therapeutic effects of ICI alone appear to be limited to recurrent GBM [71]. On the other hand, ICIs may be effective if used as neoadjuvant therapy for resectable, recurrent GBM [72]. $\mathrm{M} 2 \mathrm{M} \varphi$ infiltration in the tumor microenvironment and the phosphatase and tensin homolog (PTEN) mutation status may affect the 
therapeutic effect of ICIs [73]. The efficacy of ICI treatment may thus be improved by combination with other treatments or by patient selection according to tumor mutation genotype. Improving the treatment efficacy of immunotherapy and establishing immune memory will lead to increased long-term survival of patients with GBM. Factors considered as combinational therapeutic targets are described below (Figures 3 and 4).

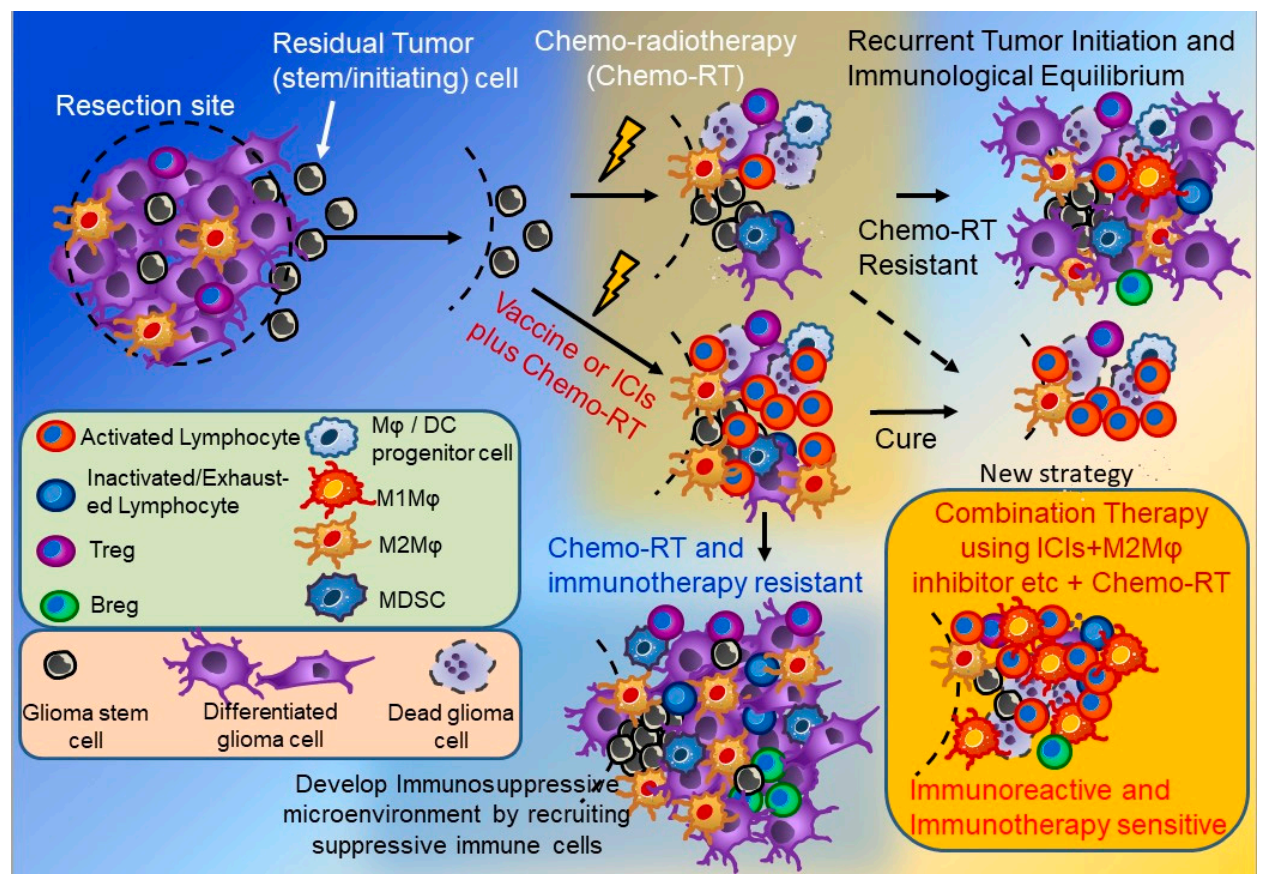

Figure 3. Therapeutic strategies for controlling immunosuppressive cells and ICI combination therapy for glioma. The immunosuppressive cell number increases after standard therapy $+/-$ ICIs in the glioma microenvironment and the tumor becomes 'cold' (blue area). ICIs plus anti-immunosuppressive cell combination therapy causes the tumor to become 'hot' (orange area).

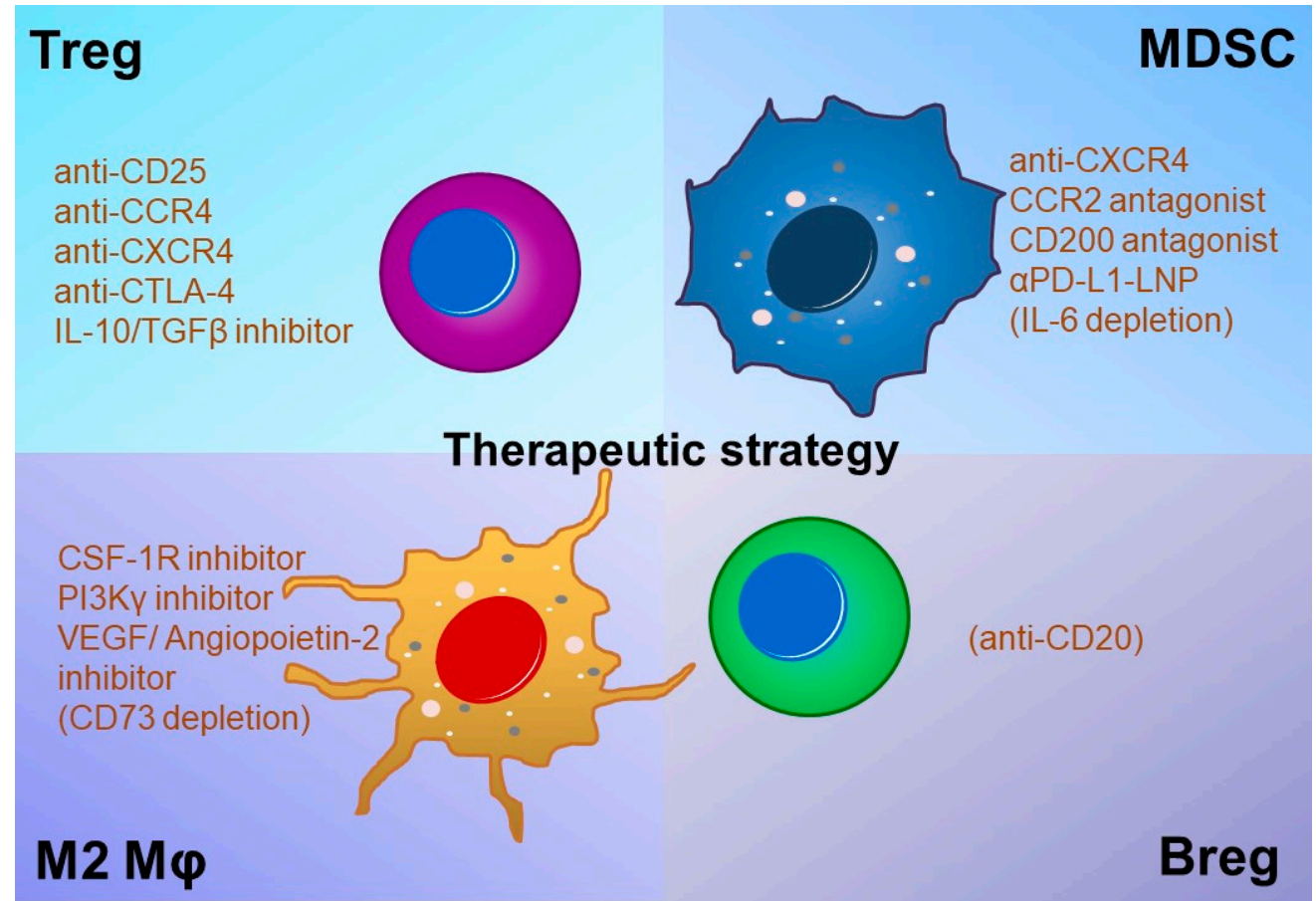

Figure 4. Treatment candidates for Tregs, $\operatorname{MDSCs}, \mathrm{M} 2 \mathrm{M} \varphi$, and Bregs in the glioma microenvironment. 


\section{Regulatory T Cells (Tregs) as a Therapeutic Target of GBM}

Tregs that mainly differentiate from the naïve T-cell fraction to suppress excessive activation of $\mathrm{T}$ cells are described as CD25 ${ }^{+}$FOXP3 $^{+}$CD 4 T cells and function to suppress antitumor immunity by effector T cells in the tumor microenvironment [74]. Tregs are classified by molecular marker expression level and by examination of their functions; thus, it has been reported that the fraction of FoxP 3 high CD45RA- CD25 high cells has strong immunosuppressive abilities, including expression of co-inhibitory ICMs, consumption of autoexpanding IL-2, production of inhibitory cytokines, consumption of nutrients, and killing activity against effector T cells [75]. For many types of malignant tumors, the proportion of Tregs in the tumor and peripheral blood and the ratio of Tregs to CD8 cells correlate with the prognosis [76-83]. In GBM, there are opposite reports regarding the relationship between Treg proportion and the CD8/Treg ratio with prognosis [84-87]. On the other hand, Treg accumulation in the tumor margins [88] and inhibitory ability in murine models have been reported [89], indicating that Tregs can also be therapeutic targets in GBM. Combination therapy targeting angiogenesis using VEGF and angiopoietin-2 inhibitors combined with anti-PD-1 antibody inhibited Treg and MDSC infiltration and increased proliferation and anti-tumor activity of glioma-infiltrating CD8 T cells [90]. Anti-CD25 antibody, anti-CCR4 antibody, anti-CXCR4 antibody, anti-CTLA-4 antibody, IL-10, and TGF $\beta$ inhibitors have been clinically developed as Treg depletion therapy (Figure 4) [91-94]. Combination therapy using Treg depletion with anti-CD25 or anti-CXCR4 antibodies and ICIs was shown to be effective in a murine glioma model [94,95]. Regarding Treg-depleting antibodies, methods of suppressing the onset of autoimmune diseases by adjusting the administration method and period are also under investigation [96,97]. However, these antibody therapies are systemically effective and may cause autoimmune adverse effects $[75,96,97]$. In addition, there are several types of Tregs: a fraction called FOXP3 $3^{\text {low }}$ 'fragile or non' Tregs with low immunosuppressive function and a truly functional fraction called FOXP3 ${ }^{\text {high }}$ 'effector' Tregs. Development of a therapy targeting these effector Tregs is required [96-98].

\section{Myeloid-Derived Suppressor Cells (MDSCs), M2 Macrophages (M2M $\varphi s)$, and Regulatory B Cells (Bregs) as Therapeutic Targets of GBM}

MDSC s are detected as a fraction of $\mathrm{CD} 11 b^{+} \mathrm{CD} 33^{+} \mathrm{HLA}^{-D R^{-}}$cells in humans and are classified

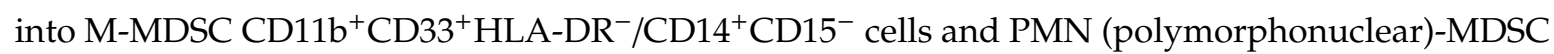

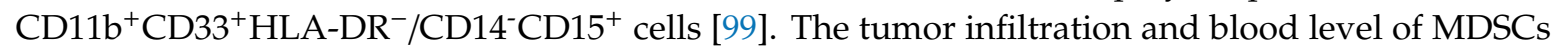
correlate with the prognosis of many types of cancers [99]. MDSCs accumulate in the tumor microenvironment and suppress anti-tumor immunity by signals-such as cytokines, chemokines, and extracellular vesicles_-secreted from tumor cells [100,101]. These bone marrow-derived cells cause immunosuppression of the tumor microenvironment not only by humoral factors such as IL-10 and TGF $\beta$, but also by ICMs, extracellular vesicles, and nutrient consumption [101]. In GBM, several reports revealed increased MDSC levels in the blood or tumor tissue as a poor prognostic factor [84,102-104]. CCL2 produced by murine GBM cells recruits CCR4 ${ }^{+}$Tregs and CCR2 ${ }^{+}$Ly-6C ${ }^{+}$mMDSCs [105] while MIF produced by tumor stem cells activates MDSCs, resulting in an immunosuppressive tumor microenvironment [105]. In addition, CD49d mRNA levels in tumor tissue, suggesting CD49d ${ }^{+}$ MDSC/TAM/Treg levels, strongly correlate with GBM prognosis [103]. On the basis of such reports, combination immunotherapy for MDSC inhibition has been developed. Representative examples are described below. Combination therapy using a CCR2 antagonist (CCX872) and anti-PD-1 antibody to inhibit MDSC recruitment into the tumor microenvironment for KR158 (HGG-like cells) and 005GSC (stem-like cells) murine models increases IFN $\gamma^{+}$TILs and prolongs overall survival [106]. Combination therapy using anti-PD-1 antibody and an inhibitor of CXCR4, a receptor for CXCL12/SDF-1 that contributes to the maintenance of tumor stem cells, also increases local infiltration of CD4/8 T cells by suppressing Treg and MDSC tumor invasion and prolongs the survival of tumor-bearing mice [94]. CD200 is required to maintain bone marrow cell homeostasis; however, it may cause exacerbation due to increased MDSC infiltration during tumor growth. Therefore, combination of a CD200 synthetic 
peptide that leads to production of anti-CD200 antibodies in the organism and inhibits MDSCs with a tumor vaccine has been developed [107]. Since IL-6 produced by glioma cells promotes PD-L1 expression of MDSCs, the immunosuppressive function of MDSC is suppressed by IL-6 KO or an anti-IL-6 antibody and the antitumor effect on glioma cells is enhanced by combination therapy using anti-PD-1 antibodies [108]. $\alpha$ PD-L1-LNP, an anti-PD-L1 antibody-conjugated lipid nanoparticle (LNP) containing a CDK inhibitor (dinaciclib), demonstrated a therapeutic effect in murine glioma models. It eliminated tumor-associated bone marrow cells (TAMCs) localized to the tumor microenvironment after RT by inducing apoptosis [109]. Owing to the strong immunosuppressive potential of MDSCs and their prognostic impact on GBM, the development of a combination therapy to inhibit MDSC infiltration is desirable.

Among immunosuppressive cells, $\mathrm{M} 2 \mathrm{M} \varphi$ s have a wide variety of functions that promote tumor growth and therefore cause strong immunosuppression when recruited into the tumor microenvironment at the early stage of tumor growth [110]. M2M $\varphi$ s enhance PD-L1 and IDO expression by antibody-dependent cellular phagocytosis [111]. It is expected that the effects of ICIs can be enhanced by combination with an $\mathrm{M} 2 \mathrm{M} \varphi$ inhibitor. In GBM, B7-H4 expression on tumor cells and tumor-associated macrophages (TAMs) results in the maintenance of glioma progenitor cells and the formation of an immunosuppressive tumor microenvironment [29] while miRNA-21 contained in exosomes produced by TAMs increases the production of PDCD4, SOX2, STAT3, IL-6, and TGF- $\beta 1$ in GBM cells that engenders TMZ resistance [112]. Conversely, exosomes derived from glioma stem cells (GSCs) promote M2 polarization and PD-L1 expression in M $\varphi s$ [113]. Hence, tumor cells and $\mathrm{M} \varphi$ s mutually regulate the survival environment. Additionally, large amounts of $\mathrm{M} \varphi \mathrm{s}$ infiltrate GBM tissues and are derived from monocytes rather than microglia [114,115]. IDO expressed by TAMs and tumor cells metabolizes tryptophan to kynurenine, and kynurenine inhibits T-cell immunity while stimulating $\mathrm{M} \varphi$ aryl hydrocarbon receptor (AHR) expression. This AHR signal increases CCR2 and CD39, an ATP/ADP-degrading ectonucleotidase, expression on TAMs, resulting in increased CCL2-induced TAM recruitment into the tumor microenvironment and subsequent rise in the environmental adenosine concentration by the ectonucleotidase activity of CD39/CD73; all of which contributes to tumor progression by suppressing T-cell immunity [31]. CD73, an AMP-degrading ectonucleotidase that functions in cooperation with CD39, is highly expressed by TAMs infiltrating GBM and is expected to be a target for combination immunotherapy [116]. In addition to treatments aimed at inhibiting the function of $\mathrm{M} \varphi \mathrm{s}$, treatments aimed at inhibiting $\mathrm{M} \varphi \mathrm{s}$ accumulation or $\mathrm{M} 1$ conversion have also been developed. However, a colony-stimulating factor-1 receptor (CSF-1R) inhibitor aimed at obstructing accumulation of $\mathrm{M} \varphi$ s that did not alter the infiltration number of TAMs suppressed M2 function and improved prognosis in a murine glioma model [117]. In addition, combination therapy using a dendritic cell (DC) vaccine and an anti-PD-1 antibody with the CSF-1R inhibitor prolonged OS in a murine model via promotion of infiltration and activation of TIL [118] IPI-549, an inhibitor of phosphatidylinositol 3-kinase $\gamma(\mathrm{PI} 3 \mathrm{~K} \gamma)$, an intracellular signal of M2M $\varphi$ s, suppresses $\mathrm{M} 2 \mathrm{M} \varphi$ s by selectively inhibiting $\mathrm{PI} 3 \mathrm{~K} \gamma\left(\mathrm{IC}_{50}: 16 \mathrm{nM}\right)$ and inducing the PI3K $\delta$-dominant $\mathrm{M} 1$ phenotype [119]. Tumor growth inhibitory effects of IPI-549 have been confirmed in combination with anti-PD-1 antibodies in lung, breast, and head/neck cancer models [120]. We have also demonstrated the antitumor effect of combination therapy using anti-PD-L1 antibody and IPI-549 in a TMZ-resistant glioma-initiating murine model [121]. Furthermore, using human GBM tissue, we revealed an $\mathrm{M} 2 \mathrm{M} \varphi$ infiltration increase during recurrence after intervention with immunotherapy as compared with the primary tumor [121]. Triple combination therapy using oncolytic herpes simplex viruses (oHSV, G47D) expressing murine IL-12 (G47D-mIL12) with anti-CTLA-4 and anti-PD-1 antibodies also induces M $\varphi$ infiltration and M1-like phenotype polarization, contributing to the eradication rate in a murine model using GSCs via increasing the $\mathrm{CD}^{+} / \mathrm{CD}^{+} \mathrm{FOXP3}^{+}$ratio [122]. 
By receiving extracellular vesicles produced by MDSC and M2M $\varphi s, B$ cells express inhibitory ICMs such as PD-L1 or CD155, thereby forming an immunosuppressive tumor microenvironment as Bregs [53]. Tumor growth was significantly suppressed by using CD20 antibody or B-cell knockout in a glioma murine model in vivo [53]. Since extracellular vesicles derived from MDSC or M2M $\varphi s$ control the immunosuppressive ability of Bregs, a therapeutic strategy for targeting MDSC, M2M $\varphi s$, or extracellular vesicles may be effective.

\section{Ongoing Clinical Trials}

A search of the NIH website (https://clinicaltrials.gov/) conducted on January 27, 2020 for ongoing immunotherapy clinical trials for GBM revealed 61 clinical trials. Excluding observational and non-interventional studies, 58 were intervention trials related to immunotherapy for GBM (Table 1). Registration status is 14 for "Active, not recruiting" and 2 for "Active, not recruiting / Has results", 2 for "Enrolling by invitation" and 39 for "Recruiting". Twenty-two of these trials were ICI-related and 11 were in combination with other immunotherapies such as adoptive immunotherapy including dendritic cell therapy, oncolytic virus therapy, IDO inhibitors, and vaccine therapy. Although there is some overlap with the abovementioned, there were 21 adoptive immunotherapies including dendritic cell therapy, TIL therapy, and CAR-T therapy; 11 oncolytic virus therapies; 4 IDO inhibitors; and 5 vaccine therapies.

Numerous phase I-II clinical trials of state-of-the-art treatments, such as a DC vaccine, ICI combination, chimeric antigen receptor (CAR)-T cell therapy, a cytomegalovirus (CMV) pp65 vaccine, and recombinant human IL-7-hybrid Fc NT-I7 (IL-7-hyFc, GX-I7), are ongoing. Phase III clinical trials included nivolumab and phase II/III clinical trials included DC therapy. Among these, immunosuppressive cells, including Tregs, MDSC, and $\mathrm{M} 2 \mathrm{M} \varphi s$ in the tumor microenvironment, are often the standard therapeutic target; however, a search of the UMIN website for clinical trials (https://upload.umin.ac.jp/) revealed that, in Japan, no active clinical trials related to immunotherapy for GBM are currently being conducted. 
Table 1. Ongoing clinical trials

\begin{tabular}{|c|c|c|c|}
\hline $\begin{array}{l}\text { Status/ } \\
\text { Phase }\end{array}$ & Study Title & Interventions & NCT Number \\
\hline $\mathrm{N} / \mathrm{A} / \mathrm{I}$ & Nivolumab With DC Vaccines for Recurrent Brain Tumors & Nivolumab + dendritic cell vaccine & NCT02529072 \\
\hline $1 / \mathrm{II}$ & $\begin{array}{l}\text { Autologous Lymphoid Effector Cells Specific Against Tumour (ALECSAT) as } \\
\text { Add on to Standard of Care in Patients with Glioblastoma }\end{array}$ & ALECSAT + radiotherapy + temozolomide & NCT02799238 \\
\hline $1 / \mathrm{I}$ & $\begin{array}{l}\text { Vaccine Therapy in Treating Patients with Newly Diagnosed Glioblastoma } \\
\text { Multiforme }\end{array}$ & $\begin{array}{l}\text { Tetanus toxoid + therapeutic autologous dendritic cells + } \\
\text { therapeutic autologous lymphocytes }\end{array}$ & NCT00639639 \\
\hline $1 / \mathrm{II}$ & Pembrolizumab in Treating Patients with Recurrent Glioblastoma & Pembrolizumab & NCT02337686 \\
\hline $1 / \mathrm{I} / \mathrm{II}$ & $\begin{array}{l}\text { INO-5401 and INO-9012 Delivered by Electroporation (EP) in Combination } \\
\text { with Cemiplimab (REGN2810) in Newly-Diagnosed Glioblastoma (GBM) }\end{array}$ & $\begin{array}{l}\text { DNA-based cancer vaccine INO-5401(hTERT, WT1, and } \\
\text { PSMA) + INO-9012 (IL-12) + cemiplimab + radiotherapy + } \\
\text { temozolomide }\end{array}$ & NCT03491683 \\
\hline $1 / \mathrm{I}$ & $\begin{array}{l}\text { DNX-2440 Oncolytic Adenovirus for Recurrent Glioblastoma } \\
\text { A Pilot Surgical Trial to Evaluate Early Immunologic Pharmacodynamic }\end{array}$ & DNX-2440 (Oncolytic Adenovirus) & NCT03714334 \\
\hline $1 / \mathrm{I}$ & $\begin{array}{l}\text { Parameters For The PD-1 Checkpoint Inhibitor, Pembrolizumab (MK-3475), } \\
\text { In Patients With Surgically Accessible Recurrent/Progressive Glioblastoma }\end{array}$ & Pembrolizumab & NCT02852655 \\
\hline $1 / \mathrm{II}$ & Avelumab in Patients with Newly Diagnosed Glioblastoma Multiforme & Avelumab & NCT03047473 \\
\hline $1 / \mathrm{II}$ & Dendritic Cell Vaccine for Patients with Brain Tumors & $\begin{array}{l}\text { Autologous tumor lysate-pulsed DC vaccination + } \\
\text { adjuvant polyICLC }\end{array}$ & NCT01204684 \\
\hline $1 / \mathrm{II}$ & $\begin{array}{l}\text { Avelumab With Hypofractionated Radiation Therapy in Adults with Isocitrate } \\
\text { Dehydrogenase (IDH) Mutant Glioblastoma }\end{array}$ & Avelumab + hypofractionated radiation therapy (HFRT) & NCT02968940 \\
\hline $1 / \mathrm{II}$ & $\begin{array}{l}\text { Convection-Enhanced Delivery (CED) of MDNA55 in Adults with Recurrent } \\
\text { or Progressive Glioblastoma }\end{array}$ & $\begin{array}{l}\text { MDNA55 (a fusion protein comprising a genetically } \\
\text { engineered Interleukin-4 (IL-4) linked to a modified version } \\
\text { of the Pseudomonas aeruginosa exotoxin A (PE)) }\end{array}$ & NCT02858895 \\
\hline $1 / \mathrm{I}$ & $\begin{array}{l}\text { Phase I Study of a Dendritic Cell Vaccine for Patients with Either Newly } \\
\text { Diagnosed or Recurrent Glioblastoma }\end{array}$ & $\begin{array}{l}\text { Dendritic cell vaccine + radiotherapy }+ \text { temozolomide } \pm \\
\text { bevacizumab }\end{array}$ & NCT02010606 \\
\hline $1 / \mathrm{II}$ & $\begin{array}{l}\text { Tremelimumab and Durvalumab in Combination or Alone in Treating Patients } \\
\text { with Recurrent Malignant Glioma }\end{array}$ & Durvalumab + tremelimumab & NCT02794883 \\
\hline $1 / \mathrm{II}$ & Combination Adenovirus + Pembrolizumab to Trigger Immune Virus Effects & DNX-2401 (Oncolytic adenovirus) + pembrolizumab & NCT02798406 \\
\hline $1 / \mathrm{I}$ & $\begin{array}{l}\text { A Phase I Study of AdV-tk + Prodrug Therapy in Combination with Radiation } \\
\text { Therapy for Pediatric Brain Tumors }\end{array}$ & $\begin{array}{l}\text { AdV-tk (an adenoviral vector (disabled virus) engineered to } \\
\text { express the Herpes thymidine kinase gene) + valacyclovir + } \\
\text { radiation }\end{array}$ & NCT00634231 \\
\hline $2 / \mathrm{II}$ & $\begin{array}{l}\text { Bevacizumab with or Without Trebananib in Treating Patients With Recurrent } \\
\text { Brain Tumors }\end{array}$ & Bevacizumab + trebananib & NCT01609790 \\
\hline 2/II & Phase 2 Study of Durvalumab (MEDI4736) in Patients with Glioblastoma & $\begin{array}{l}\text { Durvalumab + radiotherapy + temozolomide + } \\
\text { bevacizumab }\end{array}$ & NCT02336165 \\
\hline
\end{tabular}


Table 1. Cont.

\begin{tabular}{|c|c|c|c|}
\hline $\begin{array}{l}\text { Status/ } \\
\text { Phase }\end{array}$ & Study Title & Interventions & NCT Number \\
\hline 3/II/III & Proteome-Based Personalized Immunotherapy of Glioblastoma & $\begin{array}{l}\text { Dendritic vaccine }+ \text { allogeneic hematopoietic stem cells }+ \\
\text { cytotoxic lymphocytes }\end{array}$ & NCT01759810 \\
\hline $3 / \mathrm{I}$ & Immunogene-modified T (IgT) Cells Against Glioblastoma Multiforme & Antigen-specific IgT cells & NCT03170141 \\
\hline $4 / \mathrm{I} / \mathrm{II}$ & $\begin{array}{l}\text { Adjuvant Dendritic Cell-immunotherapy Plus Temozolomide in Glioblastoma } \\
\text { Patients }\end{array}$ & Dendritic cell vaccine + temozolomide & NCT02649582 \\
\hline $4 / \mathrm{II} / \mathrm{III}$ & $\begin{array}{l}\text { Dendritic Cell Immunotherapy Against Cancer Stem Cells in Glioblastoma } \\
\text { Patients Receiving Standard Therapy }\end{array}$ & Dendritic cell immunization + adjuvant temozolomide & NCT03548571 \\
\hline $4 / \mathrm{II}$ & $\begin{array}{l}\text { Immunotherapy Targeted Against Cytomegalovirus in Patients with } \\
\text { Newly-Diagnosed WHO Grade IV Unmethylated Glioma }\end{array}$ & $\begin{array}{l}\text { Human CMV pp65-LAMP mRNA-pulsed autologous DCs } \\
\text { containing GM CSF + temozolomide + tetanus-diphtheria } \\
\text { toxoid (Td) } \\
\text { 111-Indium-labeling of Cells for in vivo Trafficking Studies }\end{array}$ & NCT03927222 \\
\hline $4 / \mathrm{II}$ & V-Boost Immunotherapy in Glioblastoma Multiforme Brain Cancer & $\begin{array}{l}\text { V-Boost (an oral tablet which contains specially formulated } \\
\text { hydrolyzed GBM antigens along with alloantigens) }\end{array}$ & NCT03916757 \\
\hline $4 / \mathrm{II}$ & Study of DC Vaccination Against Glioblastoma & Dendritic cell vaccine + radiotherapy + temozolomide & NCT01567202 \\
\hline $4 / \mathrm{I}$ & $\begin{array}{l}\text { Pembrolizumab and Vorinostat Combined with Temozolomide for Newly } \\
\text { Diagnosed Glioblastoma } \\
\text { An Investigational Immuno-Therapy Study of Temozolomide Plus Radiation }\end{array}$ & $\begin{array}{l}\text { Pembrolizumab }+ \text { vorinostat }+ \text { temozolomide }+ \\
\text { radiotherapy }\end{array}$ & NCT03426891 \\
\hline $4 / \mathrm{III}$ & $\begin{array}{l}\text { Therapy with Nivolumab or Placebo, for Newly Diagnosed Patients with } \\
\text { Glioblastoma (GBM, a Malignant Brain Cancer) } \\
\text { An Investigational Immuno-Therapy Study of Nivolumab Compared to }\end{array}$ & Nivolumab + temozolomide + radiotherapy & NCT02667587 \\
\hline $4 / \mathrm{III}$ & $\begin{array}{l}\text { Temozolomide, Each Given with Radiation Therapy, for Newly-diagnosed } \\
\text { Patients With Glioblastoma (GBM, a Malignant Brain Cancer) }\end{array}$ & Nivolumab + temozolomide + radiotherapy & NCT02617589 \\
\hline $4 / \mathrm{I}$ & $\begin{array}{l}\text { Biomarker-Driven Therapy Using Immune Activators with Nivolumab in } \\
\text { Patients with First Recurrence of Glioblastoma }\end{array}$ & $\begin{array}{l}\text { Nivolumab + anti-GITR monoclonal antibody MK- } 4166+ \\
\text { IDO1 inhibitor INCB024360 + ipilimumab }\end{array}$ & NCT03707457 \\
\hline $4 / \mathrm{II}$ & $\begin{array}{l}\text { Radiation Therapy Plus Temozolomide and Pembrolizumab with and without } \\
\text { HSPPC-96 in Newly Diagnosed Glioblastoma (GBM) }\end{array}$ & $\begin{array}{l}\text { Pembrolizumab + HSPPC-96 (an autologous tumor-derived } \\
\text { heat shock protein peptide-complex) + temozolomide }\end{array}$ & NCT03018288 \\
\hline $4 / \mathrm{I}$ & $\begin{array}{l}\text { Nivolumab, BMS-986205, and Radiation Therapy with or without } \\
\text { Temozolomide in Treating Patients with Newly Diagnosed Glioblastoma }\end{array}$ & $\begin{array}{l}\text { IDO1 Inhibitor BMS-986205 + nivolumab + radiation } \\
\text { therapy + temozolomide }\end{array}$ & NCT04047706 \\
\hline $4 / \mathrm{I}$ & $\begin{array}{l}\text { Pembrolizumab and a Vaccine (ATL-DC) for the Treatment of Surgically } \\
\text { Accessible Recurrent Glioblastoma }\end{array}$ & $\begin{array}{l}\text { Dendritic cell tumor cell lysate vaccine }+ \text { pembrolizumab }+ \\
\text { poly ICLC }\end{array}$ & NCT04201873 \\
\hline $4 / \mathrm{I}$ & $\begin{array}{l}\text { Genetically Modified T-cells in Treating Patients with Recurrent or Refractory } \\
\text { Malignant Glioma }\end{array}$ & $\begin{array}{l}\text { IL13R } \alpha \text { 2-specific, hinge-optimized, } 41 \mathrm{BB} \text {-costimulatory } \\
\text { CAR/truncated CD19-expressing Autologous T } \\
\text { lymphocytes }\end{array}$ & NCT02208362 \\
\hline
\end{tabular}


Table 1. Cont.

\begin{tabular}{|c|c|c|c|}
\hline $\begin{array}{l}\text { Status/ } \\
\text { Phase }\end{array}$ & Study Title & Interventions & NCT Number \\
\hline $4 / \mathrm{I}$ & $\begin{array}{l}\text { IL13Ralpha2-Targeted Chimeric Antigen Receptor (CAR) T Cells with or } \\
\text { without Nivolumab and Ipilimumab in Treating Patients with Recurrent or } \\
\text { Refractory Glioblastoma }\end{array}$ & $\begin{array}{l}\text { IL13Ralpha2-specific hinge-optimized 4-1BB-co-stimulatory } \\
\text { CAR/Truncated CD19-expressing autologous TN/MEM } \\
\text { cells + ipilimumab + nivolumab }\end{array}$ & NCT04003649 \\
\hline 4/I/II & $\begin{array}{l}\text { Atezolizumab in Combination with Temozolomide and Radiation Therapy in } \\
\text { Treating Patients with Newly Diagnosed Glioblastoma }\end{array}$ & Atezolizumab + radiation therapy + temozolomide & NCT03174197 \\
\hline $4 / \mathrm{II}$ & $\begin{array}{l}\text { Immunotherapy Using Tumor Infiltrating Lymphocytes for Patients with } \\
\text { Metastatic Cancer }\end{array}$ & Young TIL + aldesleukin + cyclophosphamide & NCT01174121 \\
\hline $4 / \mathrm{I} / \mathrm{II}$ & NCT Neuro Master Match - N² $\mathrm{M}^{2}(\mathrm{NOA}-20)$ & $\begin{array}{l}\text { APG101 (a soluble CD95-Fc fusion protein) or alectinib or } \\
\text { idasanutlin or atezolizumab or vismodegib or palbociclib }\end{array}$ & NCT03158389 \\
\hline $4 / \mathrm{II}$ & $\begin{array}{l}\text { Efficiency of Vaccination with Lysate-loaded Dendritic Cells in Patients with } \\
\text { Newly Diagnosed Glioblastoma }\end{array}$ & $\begin{array}{l}\text { autologous, tumor lysate-loaded, mature dendritic cells } \\
\text { (DC) + radiation therapy + temozolomide }\end{array}$ & NCT03395587 \\
\hline $4 / \mathrm{I}$ & $\begin{array}{l}\text { Memory-Enriched T Cells in Treating Patients with Recurrent or Refractory } \\
\text { Grade III-IV Glioma }\end{array}$ & $\begin{array}{l}\text { CD19CAR-CD28-CD3zeta-EGFRt-expressing Tcm-enriched } \\
\text { T-lymphocytes + } \\
\text { CD19CAR-CD28-CD3zeta-EGFRt-expressing } \\
\text { Tn/mem-enriched T-lymphocytes }\end{array}$ & NCT03389230 \\
\hline $4 / \mathrm{I} / \mathrm{II}$ & $\begin{array}{l}\text { A Phase I/IIa Study Evaluating Temferon in Patients with Glioblastoma and } \\
\text { Unmethylated MGMT }\end{array}$ & Temferon & NCT03866109 \\
\hline $4 / \mathrm{I}$ & Phase I EGFR BATs in Newly Diagnosed Glioblastoma & EGFR BATs + radiation therapy + temozolomide & NCT03344250 \\
\hline $4 / \mathrm{I}$ & $\begin{array}{l}\text { Adoptive Cell Therapy of Autologous TIL and PD1-TIL Cells for Patients with } \\
\text { Glioblastoma Multiforme }\end{array}$ & Autologous TIL+ PD1-TIL & NCT03347097 \\
\hline $4 / \mathrm{II}$ & $\begin{array}{l}\text { Pediatric Trial of Indoximod With Chemotherapy and Radiation for Relapsed } \\
\text { Brain Tumors or Newly Diagnosed DIPG }\end{array}$ & Indoximod + partial radiation or full-dose radiation & NCT04049669 \\
\hline $4 / \mathrm{I}$ & $\begin{array}{l}\text { Combination of Immunization and Radiotherapy for Malignant Gliomas } \\
\text { (InSituVac1) }\end{array}$ & GM-CSF + Poly I:C or CAR-T or TCR-T + radiation & NCT03392545 \\
\hline $4 / \mathrm{I}$ & Avelumab With Laser Interstitial Therapy for Recurrent Glioblastoma & Avelumab + MRI-guided LITT therapy & NCT03341806 \\
\hline $4 / \mathrm{I}$ & $\begin{array}{l}\text { Genetically Engineered HSV-1 Phase } 1 \text { Study for the Treatment of Recurrent } \\
\text { Malignant Glioma }\end{array}$ & $\begin{array}{l}\text { M032 (NSC 733972) (a second-generation oncolytic herpes } \\
\text { simplex virus (oHSV)) }\end{array}$ & NCT02062827 \\
\hline $4 / \mathrm{II}$ & Non-Viral TCR Gene Therapy & $\begin{array}{l}\text { fludarabine }+ \text { cyclophosphamide }+ \text { aldesleukin }+ \text { sleeping } \\
\text { beauty transposed PBL }\end{array}$ & NCT04102436 \\
\hline $4 / \mathrm{I}$ & $\begin{array}{l}\text { Safety and Immunogenicity of Personalized Genomic Vaccine and Tumor } \\
\text { Treating Fields (TTFields) to Treat Glioblastoma }\end{array}$ & Poly-ICLC + tumor treating fields + peptides vaccine & NCT03223103 \\
\hline $4 / \mathrm{I}$ & $\begin{array}{l}\text { A Study to Evaluate the Safety, Tolerability and Immunogenicity of } \\
\text { EGFR(V)-EDV-Dox in Subjects with Recurrent Glioblastoma } \\
\text { Multiforme (GBM) }\end{array}$ & $\begin{array}{l}\text { EGFR(V)-EDV-Dox (a bacterially derived minicell which } \\
\text { packages a toxic payload, doxorubicin, into a } 400 \mathrm{~nm} \\
\text { particle which targets specific cancer cells using bispecific } \\
\text { antibodies (BsAb)) }\end{array}$ & NCT02766699 \\
\hline
\end{tabular}


Table 1. Cont.

\begin{tabular}{|c|c|c|c|}
\hline $\begin{array}{l}\text { Status/ } \\
\text { Phase }\end{array}$ & Study Title & Interventions & NCT Number \\
\hline $4 / \mathrm{II}$ & $\begin{array}{l}\text { Administration of Autologous T-Cells Genetically Engineered to Express } \\
\text { T-Cell Receptors Reactive Against Mutated Neoantigens in People with } \\
\text { Metastatic Cancer }\end{array}$ & $\begin{array}{l}\text { Cyclophosphamide }+ \text { fludarabine }+ \text { aldesleukin }+ \\
\text { individual patient TCR-Transduced PBL }+ \text { pembrolizumab }\end{array}$ & NCT03412877 \\
\hline $4 / \mathrm{I} / \mathrm{II}$ & $\begin{array}{l}\text { Dose-Escalation Study to Evaluate the Safety and Tolerability of GX-I7 in } \\
\text { Patients with Glioblastoma }\end{array}$ & $\begin{array}{l}\text { GX-I7 (a protein drug recombining human IL-7 and hybrid } \\
\text { Fc (hyFc)) }\end{array}$ & NCT03619239 \\
\hline $4 / \mathrm{I} / \mathrm{II}$ & $\begin{array}{l}\text { Study to Evaluate Safety, Tolerability, and Optimal Dose of Candidate GBM } \\
\text { Vaccine VBI-1901 in Recurrent GBM Subjects }\end{array}$ & $\begin{array}{l}\text { VBI-1901 (a polyvalent therapeutic vaccine against } \\
\text { cytomegalovirus antigen gB and pp65) + GM-CSF }\end{array}$ & NCT03382977 \\
\hline $4 / \mathrm{I}$ & Trial of C134 in Patients with Recurrent GBM & C134 (a cancer killing virus (HSV-1)) & NCT03657576 \\
\hline $4 / \mathrm{I}$ & $\begin{array}{l}\text { GMCI, Nivolumab, and Radiation Therapy in Treating Patients with Newly } \\
\text { Diagnosed High-Grade Gliomas }\end{array}$ & $\begin{array}{l}\text { AdV-tk + valacyclovir + radiation + temozolomide + } \\
\text { nivolumab }\end{array}$ & NCT03576612 \\
\hline $4 / \mathrm{I}$ & $\begin{array}{l}\text { Study of the IDO Pathway Inhibitor, Indoximod, and Temozolomide for } \\
\text { Pediatric Patients with Progressive Primary Malignant Brain Tumors }\end{array}$ & $\begin{array}{l}\text { Indoximod }+ \text { temozolomide }+ \text { conformal radiation }+ \\
\text { cyclophosphamide }+ \text { cyclophosphamide }\end{array}$ & NCT02502708 \\
\hline $4 / \mathrm{I}$ & A Study of the Treatment of Recurrent Malignant Glioma With rQNestin34.5v.2 & $\begin{array}{l}\text { rQNestin (an oncolytic viral vector made from the herpes } \\
\text { simplex virus type } 1 \text { (HSV1)) + cyclophosphamide }\end{array}$ & NCT03152318 \\
\hline $4 / \mathrm{I}$ & Phase 1b Study PVSRIPO on Recurrent Malignant Glioma in Children & polio/rhinovirus recombinant (PVSRIPO) & NCT03043391 \\
\hline $4 / \mathrm{I}$ & HSV G207 in Children with Recurrent or Refractory Cerebellar Brain Tumors & G207 (an oncolytic herpes simplex virus-1 (HSV)) & NCT03911388 \\
\hline $4 / \mathrm{I}$ & $\begin{array}{l}\text { HSV G207 Alone or With a Single Radiation Dose in Children with } \\
\text { Progressive or Recurrent Supratentorial Brain Tumors }\end{array}$ & $\begin{array}{l}\mathrm{G} 207 \text { (an oncolytic herpes simplex virus-1 (HSV)) + } \\
\text { radiation }\end{array}$ & NCT02457845 \\
\hline
\end{tabular}

Status number shows: 1 = Active, not recruiting; 2 = Active, not recruiting / has results; 3 = Enrolling by invitation; 4 = Recruiting; N/A = Not available. 


\section{Future Perspectives and Conclusions}

The most crucial point in the treatment of GBM is recurrence prevention after surgery and the development of immunotherapies to expand treatment options is welcomed. However, single immunotherapy is often insufficient in GBM and leads to formation of a 'cold tumor', since the immune microenvironment in GBM varies so greatly compared to other types of cancers. Analysis of the GBM microenvironment shows that patients with poor prognosis often have infiltration of immunosuppressive cells such as Tregs, MDSC, and M2M $\varphi$ s (Figure 3). A neoantigen vaccine using comprehensive gene analysis [123], CAR-T/NK cell therapy [124-126], and oncolytic virus therapy [122,127] are also considered promising. In addition to combinations of chemotherapies, radiotherapies, and ICIs already available for other malignant tumors [128], these ongoing or future therapies targeting the above-mentioned cells or immunosuppressive function will be forthcoming. It is also important to establish minimally invasive measurement methods to assay changes in immune status, such as liquid biopsy using the blood or cerebrospinal fluid of GBM patients [129].

In conclusion, we have here reviewed epidemiological features, tumor immune microenvironment, and associations between ICM expression and GBM prognosis. We have also reviewed the various ongoing and future immunotherapies for GBM. Various strategies, such as combinations of ICI therapies, will overcome these immunosuppressive mechanisms in the immune microenvironment of GBM.

Author Contributions: Conceptualization, E.I. and T.M.; methodology, E.I. and T.M.; writing—original draft preparation, E.I. and T.M.; writing-review and editing, N.S. and M.M.; visualization, E.I. and T.M.; supervision, E.I.; project administration, E.I.; funding acquisition, E.I. All authors have read and agree to the published version of the manuscript.

Funding: This study was funded by a Grant-in-Aid for Scientific Research (research number 18K08962) from the Japanese Ministry of Education, Culture, Sports, Science and Technology (MEXT) and by the Project for Promotion of Practical Applications of Advanced Medical Technologies at Tsukuba University Hospital.

Acknowledgments: The authors thank Alexander Zaboronok, Department of Neurosurgery, for critical revision. The authors would also like to thank Flaminia Miyamasu of the Medical English Communications Center of the Faculty of Medicine, University of Tsukuba, for language revision.

Conflicts of Interest: The authors have no conflicts of interest directly relevant to the content of this article. As indirect relevance, some of the materials for the AFTV described in this review article was provided by Cell-Medicine, Inc. (CMI), which is a venture company for research and development of immunotherapy born from RIKEN (The Institute of Physical and Chemical Research) and University of Tsukuba in Japan. T.M. is a member of CMI.

\section{Abbreviations}

$\begin{array}{ll}\text { AFTV } & \text { autologous formalin-fixed tumor vaccine } \\ \text { AHR } & \text { aryl hydrocarbon receptor } \\ \text { ATRX } & \alpha \text {-thalassemia/mental retardation X-linked } \\ \text { BRAF } & \text { v-raf murine sarcoma viral oncogene homolog B1 } \\ \text { BRM } & \text { biological response modifier } \\ \text { CAR } & \text { chimeric antigen receptor } \\ \text { CMV } & \text { cytomegalovirus } \\ \text { CSF-1 } & \text { colony-stimulating factor-1 } \\ \text { CTLA-4 } & \text { cytotoxic T lymphocyte antigen-4 } \\ \text { DC } & \text { dendritic cell } \\ \text { EGFR } & \text { epidermal growth factor receptor } \\ \text { FOXP3 } & \text { forkhead box protein P3 } \\ \text { GARP } & \text { glycoprotein A repetitions predominant } \\ \text { GBM } & \text { glioblastoma } \\ \text { GSC } & \text { glioma stem cell } \\ \text { ICI } & \text { immune checkpoint inhibitor } \\ \text { ICM } & \text { immune checkpoint molecule }\end{array}$




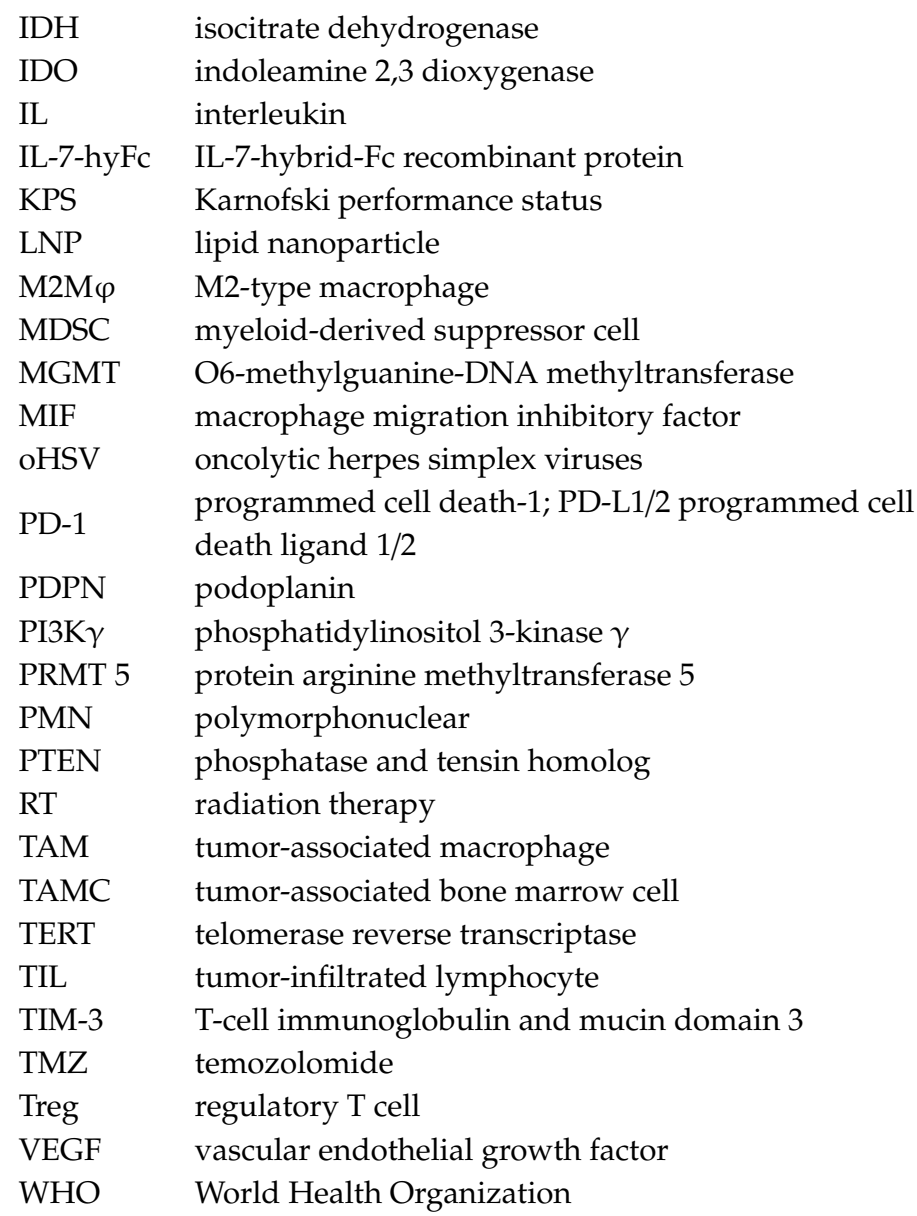

\section{References}

1. Committee of Brain Tumor Registry of Japan. Brain Tumor Registry of Japan (2005-2008). Neurol. Med. Chir. 2017, 57 (Suppl. 1), 9-102. [CrossRef] [PubMed]

2. Crocetti, E.; Trama, A.; Stiller, C.; Caldarella, A.; Soffietti, R.; Jaal, J.; Weber, D.C.; Ricardi, U.; Slowinski, J.; Brandes, A. RARECARE working group. Epidemiology of glial and non-glial brain tumours in Europe. Eur. J. Cancer 2012, 48, 1532-1542. [CrossRef] [PubMed]

3. Ostrom, Q.T.; Gittleman, H.; Truitt, G.; Boscia, A.; Kruchko, C.; Barnholtz-Sloan, J.S. CBTRUS Statistical Report: Primary Brain and Other Central Nervous System Tumors Diagnosed in the United States in 2011-2015. Neuro Oncol. 2015, 20 (Suppl. 4), iv1-iv86. [CrossRef]

4. Stupp, R.; Mason, W.P.; van den Bent, M.J.; Weller, M.; Fisher, B.; Taphoorn, M.J.; Belanger, K.; Brandes, A.A.; Marosi, C.; Bogdahn, U.; et al. European Organisation for Research and Treatment of Cancer Brain Tumor and Radiotherapy Groups; National Cancer Institute of Canada Clinical Trials Group. Radiotherapy plus concomitant and adjuvant temozolomide for glioblastoma. N. Engl. J. Med. 2005, 352, 987-996. [CrossRef] [PubMed]

5. Gorlia, T.; Stupp, R.; Brandes, A.A.; Rampling, R.R.; Fumoleau, P.; Dittrich, C.; Campone, M.M.; Twelves, C.C.; Raymond, E.; Hegi, M.E.; et al. New prognostic factors and calculators for outcome prediction in patients with recurrent glioblastoma: A pooled analysis of EORTC Brain Tumour Group phase I and II clinical trials. Eur. J. Cancer 2012, 48, 1176-1184. [CrossRef] [PubMed]

6. Park, J.K.; Hodges, T.; Arko, L.; Shen, M.; Dello Iacono, D.; Nabb, A.M.; Bailey, N.O.; Kreisl, T.N.; Iwamoto, F.M.; Sul, J.; et al. Scale to predict survival after surgery for recurrent glioblastoma multiforme. J. Clin. Oncol. 2010, 28, 3838-3843. [CrossRef] [PubMed]

7. Vredenburgh, J.J.; Desjardins, A.; Herndon, J.E., 2nd; Marcello, J.; Reardon, D.A.; Quinn, J.A.; Rich, J.N.; Sathornsumetee, S.; Gururangan, S.; Sampson, J.; et al. Bevacizumab plus irinotecan in recurrent glioblastoma multiforme. J. Clin. Oncol. 2007, 25, 4722-4729. [CrossRef] 
8. Westphal, M.; Hilt, D.C.; Bortey, E.; Delavault, P.; Olivares, R.; Warnke, P.C.; Whittle, I.R.; Jääskeläinen, J.; Ram, Z. A phase 3 trial of local chemotherapy with biodegradable carmustine (BCNU) wafers (Gliadel wafers) in patients with primary malignant glioma. Neuro Oncol. 2003, 5, 79-88. [CrossRef]

9. Sandmann, T.; Bourgon, R.; Garcia, J.; Li, C.; Cloughesy, T.; Chinot, O.L.; Wick, W.; Nishikawa, R.; Mason, W.; Henriksson, R.; et al. Patients With Proneural Glioblastoma May Derive Overall Survival Benefit From the Addition of Bevacizumab to First-Line Radiotherapy and Temozolomide: Retrospective Analysis of the AVAglio Trial. J. Clin. Oncol. 2015, 33, 2735-2744. [CrossRef]

10. Cohen, A.L.; Colman, H. Glioma biology and molecular markers. Cancer Treat Res. 2015, 163, 15-30. [CrossRef]

11. Ludwig, K.; Kornblum, H.I. Molecular markers in glioma. J. Neurooncol. 2017, 134, 505-512. [CrossRef]

12. Karsy, M.; Neil, J.A.; Guan, J.; Mahan, M.A.; Colman, H.; Jensen, R.L. A practical review of prognostic correlations of molecular biomarkers in glioblastoma. Neurosurg. Focus 2015, 38, E4. [CrossRef] [PubMed]

13. Minniti, G.; Scaringi, C.; Arcella, A.; Lanzetta, G.; Di Stefano, D.; Scarpino, S.; Bozzao, A.; Pace, A.; Villani, V.; Salvati, M.; et al. IDH1 mutation and MGMT methylation status predict survival in patients with anaplastic astrocytoma treated with temozolomide-based chemoradiotherapy. J. Neurooncol. 2014, 118, 377-383. [CrossRef] [PubMed]

14. Van den Bent, M.J.; Brandes, A.A.; Taphoorn, M.J.; Kros, J.M.; Kouwenhoven, M.C.; Delattre, J.Y.; Bernsen, H.J.; Frenay, M.; Tijssen, C.C.; Grisold, W.; et al. Adjuvant procarbazine, lomustine, and vincristine chemotherapy in newly diagnosed anaplastic oligodendroglioma: Long-term follow-up of EORTC brain tumor group study 26951. J. Clin. Oncol. 2013, 31, 344-350. [CrossRef]

15. Stark, A.M.; Witzel, P.; Strege, R.J.; Hugo, H.-H.; Mehdorn, H.M. p53, mdm2, EGFR, and msh2 expression in paired initial and recurrent glioblastoma multiforme. J. Neurol. Neurosurg. Psychiatry 2003, 74, 779-783. [CrossRef]

16. Van den Bent, M.J.; Gao, Y.; Kerkhof, M.; Kros, J.M.; Gorlia, T.; van Zwieten, K.; Prince, J.; van Duinen, S.; Sillevis Smitt, P.A.; Taphoorn, M.; et al. Changes in the EGFR amplification and EGFRvIII expression between paired primary and recurrent glioblastomas. Neuro Oncol. 2015, 17, 935-941. [CrossRef] [PubMed]

17. Brown, J.R.; Wimberly, H.; Lannin, D.R.; Nixon, C.; Rimm, D.L.; Bossuyt, V. Multiplexed quantitative analysis of CD3, CD8, and CD20 predicts response to neoadjuvant chemotherapy in breast cancer. Clin. Cancer Res. 2014, 20, 5995-6005. [CrossRef] [PubMed]

18. Dahlin, A.M.; Henriksson, M.L.; Van Guelpen, B.; Stenling, R.; Oberg, A.; Rutegård, J.; Palmqvist, R. Colorectal cancer prognosis depends on T-cell infiltration and molecular characteristics of the tumor. Mod. Pathol. 2011, 24, 671-682. [CrossRef]

19. Schreiber, R.D.; Old, L.J.; Smyth, M.J. Cancer immunoediting: Integrating immunity's roles in cancer suppression and promotion. Science 2011, 331, 1565-1570. [CrossRef]

20. Gratas, C.; Tohma, Y.; Van Meir, E.G.; Klein, M.; Tenan, M.; Ishii, N.; Tachibana, O.; Kleihues, P.; Ohgaki, H. Fas ligand expression in glioblastoma cell lines and primary astrocytic brain tumors. Brain Pathol. 1997, 7, 863-869. [CrossRef]

21. Berghoff, A.S.; Kiesel, B.; Widhalm, G.; Rajky, O.; Ricken, G.; Wöhrer, A.; Dieckmann, K.; Filipits, M.; Brandstetter, A.; Weller, M.; et al. Programmed death ligand 1 expression and tumor-infiltrating lymphocytes in glioblastoma. Neuro Oncol. 2015, 17, 1064-1075. [CrossRef] [PubMed]

22. Lailler, C.; Louandre, C.; Morisse, M.C.; Lhossein, T.; Godin, C.; Lottin, M.; Constans, J.M.; Chauffert, B.; Galmiche, A.; Saidak, Z. ERK1/2 signaling regulates the immune microenvironment and macrophage recruitment in glioblastoma. Biosci. Rep. 2019, 39. [CrossRef] [PubMed]

23. Liu, Y.; Carlsson, R.; Ambjørn, M.; Hasan, M.; Badn, W.; Darabi, A.; Siesjö, P.; Issazadeh-Navikas, S. PD-L1 expression by neurons nearby tumors indicates better prognosis in glioblastoma patients. J. Neurosci. 2013, 33, 14231-14245. [CrossRef] [PubMed]

24. Miyazaki, T.; Ishikawa, E.; Matsuda, M.; Akutsu, H.; Osuka, S.; Sakamoto, N.; Takano, S.; Yamamoto, T.; Tsuboi, K.; Matsumura, A. Assessment of PD-1 positive cells on initial and secondary resected tumor specimens of newly diagnosed glioblastoma and its implications on patient outcome. J. Neurooncol. 2017, 133, 277-285. [CrossRef] [PubMed]

25. Nduom, E.K.; Wei, J.; Yaghi, N.K.; Huang, N.; Kong, L.Y.; Gabrusiewicz, K.; Ling, X.; Zhou, S.; Ivan, C.; Chen, J.Q.; et al. PD-L1 expression and prognostic impact in glioblastoma. Neuro Oncol. 2016, 18, 195-205. [CrossRef] 
26. Chen, Q.; Han, B.; Meng, X.; Duan, C.; Yang, C.; Wu, Z.; Magafurov, D.; Zhao, S.; Safin, S.; Jiang, C.; et al. Immunogenomic analysis reveals LGALS1 contributes to the immune heterogeneity and immunosuppression in glioma. Int. J. Cancer 2019, 145, 517-530. [CrossRef]

27. Yuan, F.; Ming, H.; Wang, Y.; Yang, Y.; Yi, L.; Li, T.; Ma, H.; Tong, L.; Zhang, L.; Liu, P.; et al. Molecular and clinical characterization of Galectin-9 in glioma through 1027 samples. J. Cell Physiol. 2020, 235, 4326-4334. [CrossRef]

28. Han, M.Z.; Wang, S.; Zhao, W.B.; Ni, S.L.; Yang, N.; Kong, Y.; Huang, B.; Chen, A.J.; Li, X.G.; Wang, J.; et al. Immune checkpoint molecule herpes virus entry mediator is overexpressed and associated with poor prognosis in human glioblastoma. EBioMedicine 2019, 43, 159-170. [CrossRef]

29. Yao, Y.; Ye, H.; Qi, Z.; Mo, L.; Yue, Q.; Baral, A.; Hoon, D.S.B.; Vera, J.C.; Heiss, J.D.; Chen, C.C.; et al. B7-H4(B7x)-Mediated Cross-talk between Glioma-Initiating Cells and Macrophages via the IL6/JAK/STAT3 Pathway Lead to Poor Prognosis in Glioma Patients. Clin. Cancer Res. 2016, 22, 2778-2790. [CrossRef]

30. Chahlavi, A.; Rayman, P.; Richmond, A.L.; Biswas, K.; Zhang, R.; Vogelbaum, M.; Tannenbaum, C.; Barnett, G.; Finke, J.H. Glioblastomas induce T-lymphocyte death by two distinct pathways involving gangliosides and CD70. Cancer Res. 2005, 65, 5428-5438. [CrossRef]

31. Takenaka, M.C.; Gabriely, G.; Rothhammer, V.; Mascanfroni, I.D.; Wheeler, M.A.; Chao, C.C.; Gutiérrez-Vázquez, C.; Kenison, J.; Tjon, E.C.; Barroso, A.; et al. Control of tumor-associated macrophages and T cells in glioblastoma via AHR and CD39. Nat. Neurosci. 2019, 22, 729-740. [CrossRef] [PubMed]

32. Eisemann, T.; Costa, B.; Peterziel, H.; Angel, P. Podoplanin Positive Myeloid Cells Promote Glioma Development by Immune Suppression. Front. Oncol. 2019, 9, 187. [CrossRef] [PubMed]

33. Zimmer, N.; Kim, E.; Sprang, B.; Leukel, P.; Khafaji, F.; Ringel, F.; Sommer, C.; Tuettenberg, J.; Tuettenberg, A. GARP as an Immune Regulatory Molecule in the Tumor Microenvironment of Glioblastoma Multiforme. Int. J. Mol. Sci. 2019, 20, 3676. [CrossRef]

34. Tamura, R.; Tanaka, T.; Ohara, K.; Miyake, K.; Morimoto, Y.; Yamamoto, Y.; Kanai, R.; Akasaki, Y.; Murayama, Y.; Tamiya, T.; et al. Persistent restoration to the immunosupportive tumor microenvironment in glioblastoma by bevacizumab. Cancer Sci. 2019, 110, 499-508. [CrossRef] [PubMed]

35. Otvos, B.; Silver, D.J.; Mulkearns-Hubert, E.E.; Alvarado, A.G.; Turaga, S.M.; Sorensen, M.D.; Rayman, P.; Flavahan, W.A.; Hale, J.S.; Stoltz, K.; et al. Cancer Stem Cell-Secreted Macrophage Migration Inhibitory Factor Stimulates Myeloid Derived Suppressor Cell Function and Facilitates Glioblastoma Immune Evasion. Stem. Cells 2016, 34, 2026-2039. [CrossRef] [PubMed]

36. Zisakis, A.; Piperi, C.; Themistocleous, M.S.; Korkolopoulou, P.; Boviatsis, E.I.; Sakas, D.E.; Patsouris, E.; Lea, R.W.; Kalofoutis, A. Comparative analysis of peripheral and localised cytokine secretion in glioblastoma patients. Cytokine 2007, 39, 99-105. [CrossRef]

37. Bhardwaj, R.; Suzuki, A.; Leland, P.; Joshi, B.H.; Puri, R.K. Identification of a novel role of IL-13R $\alpha 2$ in human Glioblastoma multiforme: Interleukin-13 mediates signal transduction through AP-1 pathway. J. Transl. Med. 2018, 16, 369. [CrossRef]

38. Qiu, B.; Zhang, D.; Wang, C.; Tao, J.; Tie, X.; Qiao, Y.; Xu, K.; Wang, Y.; Wu, A. IL-10 and TGF- $\beta 2$ are overexpressed in tumor spheres cultured from human gliomas. Mol. Biol. Rep. 2011, 38, 3585-3591. [CrossRef]

39. Zhou, W.; Ke, S.Q.; Huang, Z.; Flavahan, W.; Fang, X.; Paul, J.; Wu, L.; Sloan, A.E.; McLendon, R.E.; Li, X.; et al. Periostin secreted by glioblastoma stem cells recruits M2 tumour-associated macrophages and promotes malignant growth. Nat. Cell Biol. 2015, 17, 170-182. [CrossRef]

40. Kast, R.E.; Hill, Q.A.; Wion, D.; Mellstedt, H.; Focosi, D.; Karpel-Massler, G.; Heiland, T.; Halatsch, M.E. Glioblastoma-synthesized G-CSF and GM-CSF contribute to growth and immunosuppression: Potential therapeutic benefit from dapsone, fenofibrate, and ribavirin. Tumour Biol. 2017, 39. [CrossRef]

41. Feng, X.; Szulzewsky, F.; Yerevanian, A.; Chen, Z.; Heinzmann, D.; Rasmussen, R.D.; Alvarez-Garcia, V.; Kim, Y.; Wang, B.; Tamagno, I.; et al. Loss of CX3CR1 increases accumulation of inflammatory monocytes and promotes gliomagenesis. Oncotarget 2015, 6, 15077-15094. [CrossRef] [PubMed]

42. Giordano, F.A.; Link, B.; Glas, M.; Herrlinger, U.; Wenz, F.; Umansky, V.; Brown, J.M.; Herskind, C. Targeting the Post-Irradiation Tumor Microenvironment in Glioblastoma via Inhibition of CXCL12. Cancers 2019, 11, 272. [CrossRef] [PubMed]

43. Qiu, J.; Shi, Z.; Jiang, J. Cyclooxygenase-2 in glioblastoma multiforme. Drug Discov. Today 2017, 22, 148-156. [CrossRef] [PubMed] 
44. Wang, Y.; Shen, Y.; Wang, S.; Shen, Q.; Zhou, X. The role of STAT3 in leading the crosstalk between human cancers and the immune system. Cancer Lett. 2018, 415, 117-128. [CrossRef]

45. Ricklefs, F.L.; Alayo, Q.; Krenzlin, H.; Mahmoud, A.B.; Speranza, M.C.; Nakashima, H.; Hayes, J.L.; Lee, K.; Balaj, L.; Passaro, C.; et al. Immune evasion mediated by PD-L1 on glioblastoma-derived extracellular vesicles. Sci. Adv. 2018, 4, eaar2766. [CrossRef]

46. Rooj, A.K.; Mineo, M.; Godlewski, J. MicroRNA and extracellular vesicles in glioblastoma: Small but powerful. Brain Tumor. Pathol. 2016, 33, 77-88. [CrossRef]

47. Kesarwani, P.; Prabhu, A.; Kant, S.; Chinnaiyan, P. Metabolic remodeling contributes towards an immune-suppressive phenotype in glioblastoma. Cancer Immunol. Immunother. 2019, 68, 1107-1120. [CrossRef]

48. Wainwright, D.A.; Balyasnikova, I.V.; Chang, A.L.; Ahmed, A.U.; Moon, K.S.; Auffinger, B.; Tobias, A.L.; Han, Y.; Lesniak, M.S. IDO expression in brain tumors increases the recruitment of regulatory T cells and negatively impacts survival. Clin. Cancer Res. 2012, 18, 6110-6121. [CrossRef]

49. Zhai, L.; Ladomersky, E.; Lauing, K.L.; Wu, M.; Genet, M.; Gritsina, G.; Győrffy, B.; Brastianos, P.K.; Binder, D.C.; Sosman, J.A.; et al. Infiltrating T Cells Increase IDO1 Expression in Glioblastoma and Contribute to Decreased Patient Survival. Clin. Cancer Res. 2017, 23, 6650-6660. [CrossRef]

50. Xu, S.; Shao, Q.Q.; Sun, J.T.; Yang, N.; Xie, Q.; Wang, D.H.; Huang, Q.B.; Huang, B.; Wang, X.Y.; Li, X.G.; et al. Synergy between the ectoenzymes CD39 and CD73 contributes to adenosinergic immunosuppression in human malignant gliomas. Neuro Oncol. 2013, 15, 1160-1172. [CrossRef]

51. Banasavadi-Siddegowda, Y.K.; Welker, A.M.; An, M.; Yang, X.; Zhou, W.; Shi, G.; Imitola, J.; Li, C.; Hsu, S.; Wang, J.; et al. PRMT5 as a druggable target for glioblastoma therapy. Neuro Oncol. 2018, 20, 753-763. [CrossRef] [PubMed]

52. Miska, J.; Lee-Chang, C.; Rashidi, A.; Muroski, M.E.; Chang, A.L.; Lopez-Rosas, A.; Zhang, P.; Panek, W.K.; Cordero, A.; Han, Y.; et al. HIF- $1 \alpha$ Is a Metabolic Switch between Glycolytic-Driven Migration and Oxidative Phosphorylation-Driven Immunosuppression of Tregs in Glioblastoma. Cell Rep. 2019, 27, $226-237$. [CrossRef] [PubMed]

53. Lee-Chang, C.; Rashidi, A.; Miska, J.; Zhang, P.; Pituch, K.C.; Hou, D.; Xiao, T.; Fischietti, M.; Kang, S.J.; Appin, C.L.; et al. Myeloid-Derived Suppressive Cells Promote B cell-Mediated Immunosuppression via Transfer of PD-L1 in Glioblastoma. Cancer Immunol. Res. 2019, 7, 1928-1943. [CrossRef] [PubMed]

54. Pardoll, D.M. The blockade of immune checkpoints in cancer immunotherapy. Nat. Rev. Cancer 2012, 12, 252-264. [CrossRef]

55. Liu, X.; Wang, Y.; Lu, H.; Li, J.; Yan, X.; Xiao, M.; Hao, J.; Alekseev, A.; Khong, H.; Chen, T.; et al. Genome-wide analysis identifies NR4A1 as a key mediator of T cell dysfunction. Nature 2019, 567, 525-529. [CrossRef]

56. Sharma, P.; Allison, J.P. The future of immune checkpoint therapy. Science 2015, 348, 56-61. [CrossRef]

57. Borghaei, H.; Paz-Ares, L.; Horn, L.; Spigel, D.R.; Steins, M.; Ready, N.E.; Chow, L.Q.; Vokes, E.E.; Felip, E.; Holgado, E.; et al. Nivolumab versus docetaxel in advanced nonsquamous non-small-cell lung cancer. N. Engl. J. Med. 2015, 373, 1627-1639. [CrossRef]

58. Robert, C.; Long, G.V.; Brady, B.; Dutriaux, C.; Maio, M.; Mortier, L.; Hassel, J.C.; Rutkowski, P.; McNeil, C.; Kalinka-Warzocha, E.; et al. Nivolumab in previously untreated melanoma without BRAF mutation. N. Engl. J. Med. 2015, 372, 320-330. [CrossRef]

59. Zhang, M.; Sun, H.; Zhao, S.; Wang, Y.; Pu, H.; Wang, Y.; Zhang, Q. Expression of PD-L1 and prognosis in breast cancer: A meta-analysis. Oncotarget 2017, 8, 31347-31354. [CrossRef]

60. Duechler, M.; Peczek, L.; Zuk, K.; Zalesna, I.; Jeziorski, A.; Czyz, M. The heterogeneous immune microenvironment in breast cancer is affected by hypoxia-related genes. Immunobiology 2014, 219, 158-165. [CrossRef]

61. Platten, M.; Ochs, K.; Lemke, D.; Opitz, C.; Wick, W. Microenvironmental clues for glioma immunotherapy. Curr. Neurol. Neurosci. Rep. 2014, 14, 440. [CrossRef] [PubMed]

62. Tamura, R.; Tanaka, T.; Akasaki, Y.; Murayama, Y.; Yoshida, K.; Sasaki, H. The role of vascular endothelial growth factor in the hypoxic and immunosuppressive tumor microenvironment: Perspectives for therapeutic implications. Med. Oncol. 2019, 37, 2. [CrossRef] [PubMed]

63. Dobosz, P.; Dzieciątkowski, T. The Intriguing History of Cancer Immunotherapy. Front. Immunol. 2019, 10, 2965. [CrossRef] [PubMed] 
64. Ishikawa, E.; Tsuboi, K.; Yamamoto, T.; Muroi, A.; Takano, S.; Enomoto, T.; Matsumura, A.; Ohno, T. Clinical trial of autologous formalin-fixed tumor vaccine for glioblastoma multiforme patients. Cancer Sci. 2007, 98, 1226-1233. [CrossRef] [PubMed]

65. Tsuboi, K.; Saijo, K.; Ishikawa, E.; Tsurushima, H.; Takano, S.; Morishita, Y.; Ohno, T. Effects of local injection of ex vivo expanded autologous tumor-specific $\mathrm{T}$ lymphocytes in cases with recurrent malignant gliomas. Clin. Cancer Res. 2003, 9, 3294-3302. [PubMed]

66. Ishikawa, E.; Tsuboi, K.; Saijo, K.; Harada, H.; Takano, S.; Nose, T.; Ohno, T. Autologous natural killer cell therapy for human recurrent malignant glioma. Anticancer Res. 2004, 24, 1861-1871.

67. Muragaki, Y.; Maruyama, T.; Iseki, H.; Tanaka, M.; Shinohara, C.; Takakura, K.; Tsuboi, K.; Yamamoto, T.; Matsumura, A.; Matsutani, M.; et al. Phase I/IIa trial of autologous formalin-fixed tumor vaccine concomitant with fractionated radiotherapy for newly diagnosed glioblastoma. Clin. Artic. J. Neurosurg. 2011, 115, 248-255. [CrossRef]

68. Ishikawa, E.; Muragaki, Y.; Yamamoto, T.; Maruyama, T.; Tsuboi, K.; Ikuta, S.; Hashimoto, K.; Uemae, Y.; Ishihara, T.; Matsuda, M.; et al. Phase I/IIa trial of fractionated radiotherapy, temozolomide, and autologous formalin-fixed tumor vaccine for newly diagnosed glioblastoma. J. Neurosurg. 2014, 121, 543-553. [CrossRef]

69. Ishikawa, E.; Yamamoto, T.; Matsumura, A. Prospect of Immunotherapy for Glioblastoma: Tumor Vaccine, Immune Checkpoint Inhibitors and Combination Therapy. Neurol. Med. Chir. 2017, 57, 321-330. [CrossRef]

70. Sakamoto, N.; Ishikawa, E.; Yamamoto, T.; Satomi, K.; Nakai, K.; Sato, M.; Enomoto, T.; Morishita, Y.; Takano, S.; Ohno, T.; et al. Pathological changes after autologous formalin-fixed tumor vaccine therapy combined with temozolomide for glioblastoma-three case reports. Neurol. Med. Chir. 2011, 51, 319-325. [CrossRef]

71. Omuro, A.; Vlahovic, G.; Lim, M.; Sahebjam, S.; Baehring, J.; Cloughesy, T.; Voloschin, A.; Ramkissoon, S.H.; Ligon, K.L.; Latek, R.; et al. Nivolumab with or without ipilimumab in patients with recurrent glioblastoma: Results from exploratory phase I cohorts of CheckMate 143. Neuro Oncol. 2018, 20, 674-686. [CrossRef] [PubMed]

72. Cloughesy, T.F.; Mochizuki, A.Y.; Orpilla, J.R.; Hugo, W.; Lee, A.H.; Davidson, T.B.; Wang, A.C.; Ellingson, B.M.; Rytlewski, J.A.; Sanders, C.M.; et al. Neoadjuvant anti-PD-1 immunotherapy promotes a survival benefit with intratumoral and systemic immune responses in recurrent glioblastoma. Nat. Med. 2019, 25, 477-486. [CrossRef] [PubMed]

73. Zhao, J.; Chen, A.X.; Gartrell, R.D.; Silverman, A.M.; Aparicio, L.; Chu, T.; Bordbar, D.; Shan, D.; Samanamud, J.; Mahajan, A.; et al. Immune and genomic correlates of response to anti-PD-1 immunotherapy in glioblastoma. Nat. Med. 2019, 25, 462-469. [CrossRef] [PubMed]

74. Hori, S.; Nomura, T.; Sakaguchi, S. Control of regulatory T cell development by the transcription factor Foxp3. Science 2003, 299, 1057-1061. [CrossRef]

75. Ohue, Y.; Nishikawa, H. Regulatory T (Treg) cells in cancer: Can Treg cells be a new therapeutic target? Cancer Sci. 2019, 110, 2080-2089. [CrossRef]

76. Zhou, J.; Ding, T.; Pan, W.; Zhu, L.Y.; Li, L.; Zheng, L. Increased intratumoral regulatory T cells are related to intratumoral macrophages and poor prognosis in hepatocellular carcinoma patients. Int. J. Cancer 2009, 125, 1640-1648. [CrossRef]

77. Davidsson, S.; Ohlson, A.L.; Andersson, S.O.; Fall, K.; Meisner, A.; Fiorentino, M.; Andrén, O.; Rider, J.R. CD4 helper T cells, CD8 cytotoxic T cells, and FOXP3(+) regulatory T cells with respect to lethal prostate cancer. Mod. Pathol. 2013, 26, 448-455. [CrossRef]

78. Ino, Y.; Yamazaki-Itoh, R.; Shimada, K.; Iwasaki, M.; Kosuge, T.; Kanai, Y.; Hiraoka, N. Immune cell infiltration as an indicator of the immune microenvironment of pancreatic cancer. Br. J. Cancer 2013, 108, 914-923. [CrossRef]

79. Jiang, W.; Liu, K.; Guo, Q.; Cheng, J.; Shen, L.; Cao, Y.; Wu, J.; Shi, J.; Cao, H.; Liu, B.; et al. Tumor-infiltrating immune cells and prognosis in gastric cancer: A systematic review and meta-analysis. Oncotarget 2017, 8, 62312-62329. [CrossRef]

80. Märkl, B.; Paul, B.; Schaller, T.; Kretsinger, H.; Kriening, B.; Schenkirsch, G. The role of lymph node size and FOXP3+ regulatory T cells in node-negative colon cancer. J. Clin. Pathol. 2017, 70, 443-447. [CrossRef] 
81. Papaioannou, E.; Sakellakis, M.; Melachrinou, M.; Tzoracoleftherakis, E.; Kalofonos, H.; Kourea, E. A Standardized Evaluation Method for FOXP3+ Tregs and CD8+ T-cells in Breast Carcinoma: Association with Breast Carcinoma Subtypes, Stage and Prognosis. Anticancer Res. 2019, 39, 1217-1232. [CrossRef] [PubMed]

82. Salama, P.; Phillips, M.; Grieu, F.; Morris, M.; Zeps, N.; Joseph, D.; Platell, C.; Iacopetta, B. Tumor-infiltrating FOXP3+ T regulatory cells show strong prognostic significance in colorectal cancer. J. Clin. Oncol. 2009, 27, 186-192. [CrossRef] [PubMed]

83. Yeong, J.; Thike, A.A.; Lim, J.C.; Lee, B.; Li, H.; Wong, S.C.; Hue, S.S.; Tan, P.H.; Iqbal, J. Higher densities of Foxp3+ regulatory $\mathrm{T}$ cells are associated with better prognosis in triple-negative breast cancer. Breast Cancer Res. Treat. 2017, 163, 21-35. [CrossRef] [PubMed]

84. Han, S.; Zhang, C.; Li, Q.; Dong, J.; Liu, Y.; Huang, Y.; Jiang, T.; Wu, A. Tumour-infiltrating CD4(+) and CD8(+) lymphocytes as predictors of clinical outcome in glioma. Br. J. Cancer 2014, 110, 2560-2568. [CrossRef]

85. Pereira, M.B.; Barros, L.R.C.; Bracco, P.A.; Vigo, A.; Boroni, M.; Bonamino, M.H.; Lenz, G. Transcriptional characterization of immunological infiltrates and their relation with glioblastoma patients overall survival. Oncoimmunology 2018, 7, e1431083. [CrossRef] [PubMed]

86. Sayour, E.J.; McLendon, P.; McLendon, R.; De Leon, G.; Reynolds, R.; Kresak, J.; Sampson, J.H.; Mitchell, D.A. Increased proportion of FoxP3 + regulatory $\mathrm{T}$ cells in tumor infiltrating lymphocytes is associated with tumor recurrence and reduced survival in patients with glioblastoma. Cancer Immunol. Immunother. 2015, 64, 419-427. [CrossRef]

87. Thomas, A.A.; Fisher, J.L.; Rahme, G.J.; Hampton, T.H.; Baron, U.; Olek, S.; Schwachula, T.; Rhodes, C.H.; Gui, J.; Tafe, L.J.; et al. Regulatory T Cells Are Not a Strong Predictor of Survival for Patients With Glioblastoma. Neuro Oncol. 2015, 17, 801-809. [CrossRef]

88. Tamura, R.; Ohara, K.; Sasaki, H.; Morimoto, Y.; Kosugi, K.; Yoshida, K.; Toda, M. Difference in Immunosuppressive Cells Between Peritumoral Area and Tumor Core in Glioblastoma. World Neurosurg. 2018, 120, e601-e610. [CrossRef]

89. Fecci, P.E.; Mitchell, D.A.; Whitesides, J.F.; Xie, W.; Friedman, A.H.; Archer, G.E.; Herndon, J.E., 2nd; Bigner, D.D.; Dranoff, G.; Sampson, J.H. Increased regulatory T-cell fraction amidst a diminished CD4 compartment explains cellular immune defects in patients with malignant glioma. Cancer Res. 2006, 66, 3294-3302. [CrossRef]

90. Di Tacchio, M.; Macas, J.; Weissenberger, J.; Sommer, K.; Bähr, O.; Steinbach, J.P.; Senft, C.; Seifert, V.; Glas, M.; Herrlinger, U.; et al. Tumor Vessel Normalization, Immunostimulatory Reprogramming, and Improved Survival in Glioblastoma with Combined Inhibition of PD-1, Angiopoietin-2, and VEGF. Cancer Immunol. Res. 2019, 7, 1910-1927. [CrossRef]

91. Jacobs, J.F.; Punt, C.J.; Lesterhuis, W.J.; Sutmuller, R.P.; Brouwer, H.M.; Scharenborg, N.M.; Klasen, I.S.; Hilbrands, L.B.; Figdor, C.G.; de Vries, I.J.; et al. Dendritic cell vaccination in combination with anti-CD25 monoclonal antibody treatment: A phase I/II study in metastatic melanoma patients. Clin. Cancer Res. 2010, 16, 5067-5078. [CrossRef] [PubMed]

92. Kurose, K.; Ohue, Y.; Wada, H.; Iida, S.; Ishida, T.; Kojima, T.; Doi, T.; Suzuki, S.; Isobe, M.; Funakoshi, T.; et al. Phase Ia Study of FoxP3+ CD4 Treg Depletion by Infusion of a Humanized Anti-CCR4 Antibody, KW-0761, in Cancer Patients. Clin. Cancer Res. 2015, 21, 4327-4336. [CrossRef] [PubMed]

93. Rech, A.J.; Mick, R.; Martin, S.; Recio, A.; Aqui, N.A.; Powell, D.J., Jr.; Colligon, T.A.; Trosko, J.A.; Leinbach, L.I.; Pletcher, C.H.; et al. CD25 blockade depletes and selectively reprograms regulatory $\mathrm{T}$ cells in concert with immunotherapy in cancer patients. Sci. Transl. Med. 2012, 4, 134ra62. [CrossRef] [PubMed]

94. Wu, A.; Maxwell, R.; Xia, Y.; Cardarelli, P.; Oyasu, M.; Belcaid, Z.; Kim, E.; Hung, A.; Luksik, A.S.; Garzon-Muvdi, T.; et al. Combination anti-CXCR4 and anti-PD-1 immunotherapy provides survival benefit in glioblastoma through immune cell modulation of tumor microenvironment. J. Neurooncol. 2019, 143, 241-249. [CrossRef] [PubMed]

95. Grauer, O.M.; Nierkens, S.; Bennink, E.; Toonen, L.W.; Boon, L.; Wesseling, P.; Sutmuller, R.P.; Adema, G.J. $\mathrm{CD} 4+\mathrm{FoxP} 3+$ regulatory $\mathrm{T}$ cells gradually accumulate in gliomas during tumor growth and efficiently suppress anti glioma immune responses in vivo. Int. J. Cancer 2007, 121, 95-105. [CrossRef] [PubMed]

96. Tanaka, A.; Sakaguchi, S. Targeting Treg cells in cancer immunotherapy. Eur. J. Immunol. 2019, 49, 1140-1146. [CrossRef] 
97. Overacre-Delgoffe, A.E.; Vignali, D.A.A. Treg Fragility: A Prerequisite for Effective Antitumor Immunity? Cancer Immunol. Res. 2018, 6, 882-887. [CrossRef]

98. Tanaka, A.; Sakaguchi, S. Regulatory T cells in cancer immunotherapy. Cell Res. 2017, 27, 109-118. [CrossRef]

99. Law, A.M.K.; Valdes-Mora, F.; Gallego-Ortega, D. Myeloid-Derived Suppressor Cells as a Therapeutic Target for Cancer. Cells 2020, 9, 561. [CrossRef]

100. Domenis, R.; Cesselli, D.; Toffoletto, B.; Bourkoula, E.; Caponnetto, F.; Manini, I.; Beltrami, A.P.; Ius, T.; Skrap, M.; Di Loreto, C.; et al. Systemic T Cells Immunosuppression of Glioma Stem Cell-Derived Exosomes Is Mediated by Monocytic Myeloid-Derived Suppressor Cells. PLoS ONE 2017, 12, e0169932. [CrossRef]

101. Fleming, V.; Hu, X.; Weber, R.; Nagibin, V.; Groth, C.; Altevogt, P.; Utikal, J.; Umansky, V. Targeting Myeloid-Derived Suppressor Cells to Bypass Tumor-Induced Immunosuppression. Front. Immunol. 2018, 9 , 398. [CrossRef] [PubMed]

102. Alban, T.J.; Alvarado, A.G.; Sorensen, M.D.; Bayik, D.; Volovetz, J.; Serbinowski, E.; Mulkearns-Hubert, E.E.; Sinyuk, M.; Hale, J.S.; Onzi, G.R.; et al. Global immune fingerprinting in glioblastoma patient peripheral blood reveals immune-suppression signatures associated with prognosis. JCI Insight 2018, 3, 122264. [CrossRef] [PubMed]

103. Cho, H.R.; Jeon, H.; Park, C.K.; Park, S.H.; Choi, S.H. Radiogenomics Profiling for Glioblastoma-related Immune Cells Reveals CD49d Expression Correlation with MRI parameters and Prognosis. Sci. Rep. 2018, 8, 16022. [CrossRef] [PubMed]

104. Gustafson, M.P.; Lin, Y.; LaPlant, B.; Liwski, C.J.; Maas, M.L.; League, S.C.; Bauer, P.R.; Abraham, R.S.; Tollefson, M.K.; Kwon, E.D.; et al. Immune monitoring using the predictive power of immune profiles. J. Immunother. Cancer 2013, 1, 7. [CrossRef]

105. Chang, A.L.; Miska, J.; Wainwright, D.A.; Dey, M.; Rivetta, C.V.; Yu, D.; Kanojia, D.; Pituch, K.C.; Qiao, J.; Pytel, P.; et al. CCL2 Produced by the Glioma Microenvironment Is Essential for the Recruitment of Regulatory T Cells and Myeloid-Derived Suppressor Cells. Cancer Res. 2016, 76, 5671-5682. [CrossRef]

106. Flores-Toro, J.A.; Luo, D.; Gopinath, A.; Sarkisian, M.R.; Campbell, J.J.; Charo, I.F.; Singh, R.; Schall, T.J.; Datta, M.; Jain, R.K.; et al. CCR2 inhibition reduces tumor myeloid cells and unmasks a checkpoint inhibitor effect to slow progression of resistant murine gliomas. Proc. Natl. Acad. Sci. USA 2020, 117, 1129-1138. [CrossRef]

107. Moertel, C.L.; Xia, J.; LaRue, R.; Waldron, N.N.; Andersen, B.M.; Prins, R.M.; Okada, H.; Donson, A.M.; Foreman, N.K.; Hunt, M.A.; et al. CD200 in CNS tumor-induced immunosuppression: The role for CD200 pathway blockade in targeted immunotherapy. J. Immunother. Cancer 2014, 2, 46. [CrossRef]

108. Lamano, J.B.; Lamano, J.B.; Li, Y.D.; DiDomenico, J.D.; Choy, W.; Veliceasa, D.; Oyon, D.E.; Fakurnejad, S.; Ampie, L.; Kesavabhotla, K.; et al. Glioblastoma-Derived IL6 Induces Immunosuppressive Peripheral Myeloid Cell PD-L1 and Promotes Tumor Growth. Clin. Cancer Res. 2019, 25, 3643-3657. [CrossRef]

109. Zhang, P.; Miska, J.; Lee-Chang, C.; Rashidi, A.; Panek, W.K.; An, S.; Zannikou, M.; Lopez-Rosas, A.; Han, Y.; Xiao, T; et al. Therapeutic targeting of tumor-associated myeloid cells synergizes with radiation therapy for glioblastoma. Proc. Natl. Acad. Sci. USA 2019, 116, 23714-23723. [CrossRef]

110. Aras, S.; Zaidi, M.R. TAMeless traitors: Macrophages in cancer progression and metastasis. Br. J. Cancer 2017, 117, 1583-1591. [CrossRef]

111. Su, S.; Zhao, J.; Xing, Y.; Zhang, X.; Liu, J.; Ouyang, Q.; Chen, J.; Su, F.; Liu, Q.; Song, E. Immune Checkpoint Inhibition Overcomes ADCP-Induced Immunosuppression by Macrophages. Cell 2018, 175, 442-457.e23. [CrossRef]

112. Chuang, H.Y.; Su, Y.K.; Liu, H.W.; Chen, C.H.; Chiu, S.C.; Cho, D.Y.; Lin, S.Z.; Chen, Y.S.; Lin, C.M. Preclinical Evidence of STAT3 Inhibitor Pacritinib Overcoming Temozolomide Resistance via Downregulating miR-21-Enriched Exosomes from M2 Glioblastoma-Associated Macrophages. J. Clin. Med. 2019, 8, 959. [CrossRef] [PubMed]

113. Gabrusiewicz, K.; Li, X.; Wei, J.; Hashimoto, Y.; Marisetty, A.L.; Ott, M.; Wang, F.; Hawke, D.; Yu, J.; Healy, L.M.; et al. Glioblastoma stem cell-derived exosomes induce M2 macrophages and PD-L1 expression on human monocytes. Oncoimmunology 2018, 7, e1412909. [CrossRef] [PubMed]

114. Chen, Z.; Feng, X.; Herting, C.J.; Garcia, V.A.; Nie, K.; Pong, W.W.; Rasmussen, R.; Dwivedi, B.; Seby, S.; Wolf, S.A.; et al. Cellular and Molecular Identity of Tumor-Associated Macrophages in Glioblastoma. Cancer Res. 2017, 77, 2266-2278. [CrossRef] [PubMed] 
115. Chen, Z.; Hambardzumyan, D. Immune Microenvironment in Glioblastoma Subtypes. Front. Immunol. 2018, 9, 1004. [CrossRef] [PubMed]

116. Goswami, S.; Walle, T.; Cornish, A.E.; Basu, S.; Anandhan, S.; Fernandez, I.; Vence, L.; Blando, J.; Zhao, H.; Yadav, S.S.; et al. Immune profiling of human tumors identifies CD73 as a combinatorial target in glioblastoma. Nat. Med. 2020, 26, 39-46. [CrossRef] [PubMed]

117. Pyonteck, S.M.; Akkari, L.; Schuhmacher, A.J.; Bowman, R.L.; Sevenich, L.; Quail, D.F.; Olson, O.C.; Quick, M.L.; Huse, J.T.; Teijeiro, V.; et al. CSF-1R inhibition alters macrophage polarization and blocks glioma progression. Nat. Med. 2013, 19, 1264-1272. [CrossRef] [PubMed]

118. Antonios, J.P.; Soto, H.; Everson, R.G.; Moughon, D.; Orpilla, J.R.; Shin, N.P.; Sedighim, S.; Treger, J.; Odesa, S.; Tucker, A.; et al. Immunosuppressive tumor-infiltrating myeloid cells mediate adaptive immune resistance via a PD-1/PD-L1 mechanism in glioblastoma. Neuro Oncol. 2017, 19, 796-807. [CrossRef]

119. Evans, C.A.; Liu, T.; Lescarbeau, A.; Nair, S.J.; Grenier, L.; Pradeilles, J.A.; Glenadel, Q.; Tibbitts, T.; Rowley, A.M.; DiNitto, J.P.; et al. Discovery of a Selective Phosphoinositide-3-Kinase (PI3K)- $\gamma$ Inhibitor (IPI-549) as an Immuno-Oncology Clinical Candidate. ACS Med. Chem. Lett. 2016, 7, 862-867. [CrossRef]

120. Kaneda, M.M.; Messer, K.S.; Ralainirina, N.; Li, H.; Leem, C.J.; Gorjestani, S.; Woo, G.; Nguyen, A.V.; Figueiredo, C.C.; Foubert, P.; et al. PI3K $\gamma$ is a molecular switch that controls immune suppression. Nature 2016, 539, 437-442. [CrossRef]

121. Miyazaki, T.; Ishikawa, E.; Matsuda, M.; Sugii, N.; Kohzuki, H.; Akutsu, H.; Sakamoto, N.; Takano, S.; Matsumura, A. Infiltration of CD163-positive macrophages in glioma tissues after treatment with anti-PD-L1 antibody and role of PI3K $\gamma$ inhibitor as a combination therapy with anti-PD-L1 antibody in in vivo model using temozolomide-resistant murine glioma-initiating cells. Brain Tumor Pathol. 2020, 37, 41-49. [CrossRef] [PubMed]

122. Saha, D.; Martuza, R.L.; Rabkin, S.D. Macrophage Polarization Contributes to Glioblastoma Eradication by Combination Immunovirotherapy and Immune Checkpoint Blockade. Cancer Cell 2017, 32, 253-267.e5. [CrossRef] [PubMed]

123. Keskin, D.B.; Anandappa, A.J.; Sun, J.; Tirosh, I.; Mathewson, N.D.; Li, S.; Oliveira, G.; Giobbie-Hurder, A.; Felt, K.; Gjini, E.; et al. Neoantigen vaccine generates intratumoral $\mathrm{T}$ cell responses in phase Ib glioblastoma trial. Nature 2019, 565, 234-239. [CrossRef] [PubMed]

124. Akhavan, D.; Alizadeh, D.; Wang, D.; Weist, M.R.; Shepphird, J.K.; Brown, C.E. CAR T cells for brain tumors: Lessons learned and road ahead. Immunol. Rev. 2019, 290, 60-84. [CrossRef]

125. Burger, M.C.; Zhang, C.; Harter, P.N.; Romanski, A.; Strassheimer, F.; Senft, C.; Tonn, T.; Steinbach, J.P.; Wels, W.S. CAR-Engineered NK Cells for the Treatment of Glioblastoma: Turning Innate Effectors Into Precision Tools for Cancer Immunotherapy. Front. Immunol. 2019, 10, 2683. [CrossRef]

126. Harrer, D.C.; Dörrie, J.; Schaft, N. CSPG4 as Target for CAR-T-Cell Therapy of Various Tumor Entities-Merits and Challenges. Int. J. Mol. Sci. 2019, 20, 5942. [CrossRef]

127. Fukuhara, H.; Ino, Y.; Todo, T. Oncolytic virus therapy: A new era of cancer treatment at dawn. Cancer Sci. 2016, 107, 1373-1379. [CrossRef]

128. Ishikawa, E.; Muragaki, Y.; Yamamoto, T.; Ohno, T.; Matsumura, A. Vaccine Therapy of High-Grade Gliomas. Prog. Neurol. Surg. 2018, 32, 101-111. [CrossRef]

129. Saenz-Antoñanzas, A.; Auzmendi-Iriarte, J.; Carrasco-Garcia, E.; Moreno-Cugnon, L.; Ruiz, I.; Villanua, J.; Egaña, L.; Otaegui, D.; Samprón, N.; Matheu, A. Liquid Biopsy in Glioblastoma: Opportunities, Applications and Challenges. Cancers 2019, 11, 950. [CrossRef]

(C) 2020 by the authors. Licensee MDPI, Basel, Switzerland. This article is an open access article distributed under the terms and conditions of the Creative Commons Attribution (CC BY) license (http://creativecommons.org/licenses/by/4.0/). 